\title{
Review
}

\section{The Role of Digital Technologies in Operationalizing the Circular Economy Transition: A Systematic Literature Review}

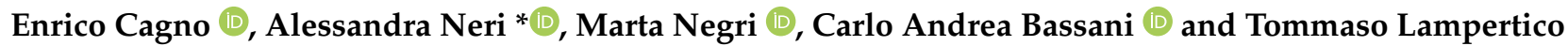

check for

updates

Citation: Cagno, E.; Neri, A.; Negri, M.; Bassani, C.A.; Lampertico, T. The Role of Digital Technologies in Operationalizing the Circular Economy Transition: A Systematic Literature Review. Appl. Sci. 2021, 11, 3328. https://doi.org/10.3390/app11 083328

Academic Editor:

Alexandre Carvalho

Received: 5 March 2021

Accepted: 6 April 2021

Published: 7 April 2021

Publisher's Note: MDPI stays neutral with regard to jurisdictional claims in published maps and institutional affiliations.

Copyright: (c) 2021 by the authors. Licensee MDPI, Basel, Switzerland. This article is an open access article distributed under the terms and conditions of the Creative Commons Attribution (CC BY) license (https:// creativecommons.org/licenses/by/ $4.0 /)$.
Department of Management, Economics and Industrial Engineering, Politecnico di Milano, Via Lambruschini $4 \mathrm{~b}$, 20156 Milan, Italy; enrico.cagno@polimi.it (E.C.); marta.negri@polimi.it (M.N.); carloandrea.bassani@mail.polimi.it (C.A.B.); tommaso.lampertico@mail.polimi.it (T.L.)

* Correspondence: alessandra.neri@polimi.it

\begin{abstract}
The enabling role of Digital Technologies towards the Circular Economy transition has been recognized. Nonetheless, to support the transition, the operationalization of the discourse is still needed. The present study performs a systematic literature review, deepening the knowledge on the role of Digital Technologies in operationalizing the Circular Economy transition. The analysis is shaped according to the ReSOLVE framework, as it has been recognized as able to operationally guide industrial firms towards the Circular Economy transition. Despite the broad focus on the topic by the extant literature, the results of the analysis show limited Circular Economy aspects addressed and specific technologies considered, making it difficult to have a complete overview on the implementation of Digital Technologies in the Circular Economy transition, operatively addressing it. Shortcomings are identified regarding the lack of an integrated and holistic analysis of the relationships, the need for investigating the decision-making process and specific Circular Economy practices, all from an empirical perspective. The paper eventually suggests streams for further research while offering theoretical and practical implications.
\end{abstract}

Keywords: circular economy; ReSOLVE; Industry 4.0; Digital Technologies; systematic literature review

\section{Introduction}

Deep and rapid economic, environmental and social changes are taking place, shaping the political, managerial and academic discourses [1,2]. The industry is not exempt from these current macro-trends and opportunities arise for two specific paradigms, namely Circular Economy (CE) and Industry 4.0 (I4.0) [3,4].

$\mathrm{CE}$ focuses on closing the material loop, shifting from a linear economy to a circular one, decreasing material extraction, waste disposal and, consequently, environmental pressure $[5,6]$. CE can be applied at different levels, namely micro (single firm, from a single product to the advertisement), meso (industrial systems and networks) and macro (society or country) [6]. Although focusing more on an environmental perspective, it is impossible to separate CE from the economy and society, which links CE to the concept of strong sustainability $[7,8]$. On the other hand, I4.0 enables intelligent factories and products, providing opportunities for enhanced performance in terms of production activities, organizational strategies, business models and skills $[9,10]$. A central role in I4.0 is played by Digital Technologies (DTs) [11].

The two concepts have been largely addressed in a separate manner; nonetheless, in the last years, they started being integrated [12]. From a general perspective, it is widely accepted that DTs can enable the CE transition [13]. DTs indeed allow more efficient and flexible processes [14], while also providing transparent access to product data and resource consumption [13]. Despite the growing interest in the role of DTs as an enabler for CE transition, some points remain still not properly addressed. Particularly, focusing on the CE micro level, the need for making the overall discourse more operational, addressing the different phases of the CE transition [15], has been underlined [16]. The Regenerate, 
Share, Optimize, Loop, Virtualize, Exchange (ReSOLVE) framework has been identified as an important tool to operationally guide industrial firms [17]; despite its relevance, only a few studies so far have focused on the enabling role of DTs in the context of the ReSOLVE framework. The majority of the contributions, indeed, still focus only on specific $\mathrm{CE}$ aspects, such as recycling or resource efficiency. On the other hand, contributions focusing on the ReSOLVE consider the role of very few and specific DTs. Both situations underlined the lack of an overall, comprehensive and integrated approach towards the investigation of the role of DTs as an enabler for CE.

Based on the considerations above, the present work aims at conducting a systematic literature review, so to better understand the possible role of DTs within the context of the ReSOLVE framework. To the best of the authors' knowledge, such an analysis is still missing, and a detailed identification of the relationships among all the available DTs and the action areas of the ReSOLVE framework needs to be investigated.

The remainder of the paper is structured as follows. We provided a background on the frameworks for the analysis of CE and DTs (Section 2). Following, we described the systematic literature review methodology, clearly outlining the steps (Section 3). After a descriptive evaluation of the results (Section 4), we analyzed the literature in terms of emerging themes, addressing the possible role of DTs in the context of the ReSOLVE framework (Section 5). We then discussed some specific issues for which additional research is necessary (Section 6). Finally (Section 7), we outlined pivotal implications of our study and paved the way for further research.

\section{Materials}

The section introduces the frameworks used in the present work for the analysis of the literature, in terms of content for both CE and DTs. As anticipated in the previous section, to understand if and how DTs can enable the CE transition, we focused on the relationship between DTs and the ReSOLVE framework. Particularly, as a limited set of contributions addresses directly the ReSOLVE framework and its different action areas, we decided to further link specific CE aspects to the ReSOLVE areas.

\subsection{Circular Economy}

Despite the soaring relevance of $\mathrm{CE}$ in the current debate, a common definition and agreement on pivotal concepts is not easy to find $[6,18]$. Nonetheless, to allow the CE transition in the industrial sector, the concept must be disclosed from a concrete viewpoint; this would support industrial firms to fully exploit resources while maintaining their value and minimizing environmental impact [19].

Among the different frameworks conceptualizing the $\mathrm{CE}$, the discourse has been largely focused on the 3Rs (Reduce, Reuse, Recycle) model [20]. The model soon evolved into the 6Rs model (Redesign, Reduce, Reuse, Remanufacture, Recycle, Recover) and then into the 9(10)Rs model (Refuse, Redesign, Reduce, Reuse, Repair, Refurbish, Remanufacture, Repurpose, Recycle, Recover) [6,21]. The Rs or waste hierarchy models have been included in the butterfly diagram [22] proposed by the Ellen MacArthur Foundation [23]. Following a cradle-to-cradle approach, the diagram highlights the difference between the loop for biological and technical nutrients. As for the technical loop, activities such as reuse, refurbishment and remanufacturing are strongly recommended [24]. Focusing on the need for industrial firms to move from linear to circular modes of production, and particularly on the opportunities deriving by the technical loop [25], the Ellen MacArthur Foundation [26] developed the ReSOLVE framework. The framework entails major circular business opportunities [27]. It proposes six areas of actions for implementing the CE transition, namely: Regenerate, Share, Optimize, Loop, Virtualize and Exchange (Figure 1). 


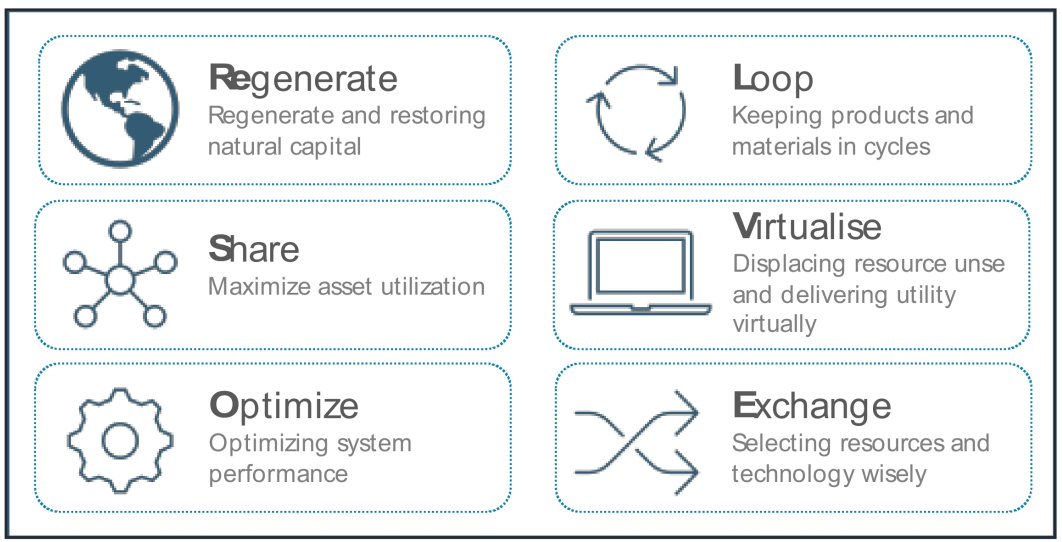

Figure 1. The Regenerate, Share, Optimize, Loop, Virtualize, Exchange (ReSOLVE) framework. Adapted from [26,28].

Several strategies can be related to the six areas [27,29], allowing the definition of operational actions for the $\mathrm{CE}$ transition [30]. A comprehensive and largely shared overview of possible $\mathrm{CE}$ operational actions for the $\mathrm{CE}$ transition is offered by Rosa et al. [31], who identified 10 aspects: Circular Business Model (CBM), i.e., the overarching concept; Digital Transformation (DIGIT); Disassembly (DISAS); Lifecycle Management (LIFEC); Recycling (RECYC); Remanufacturing (REMAN); Resource Efficiency (RESOU); Reuse (REUSE); Smart Services (SMSER) and Supply Chain Management (SCM). Leveraging on the indications provided by Kalmykova et al. [29] and Lewandowski [27], we linked the $10 \mathrm{CE}$ aspects to the ReSOLVE areas (Table 1). This operation would allow a clear classification of the literature according to the ReSOLVE areas.

Table 1. Linkage of CE aspects with ReSOLVE's actions.

\begin{tabular}{cc}
\hline & Circular Business Models \\
\hline $\begin{array}{c}\text { ReSOLVE } \\
\text { Action Areas }\end{array}$ & CE Aspects \\
\hline Regenerate & Lifecycle management \\
\hline Share & Reuse \\
\hline Optimize & $\begin{array}{c}\text { Resource efficiency } \\
\text { Supply chain management }\end{array}$ \\
\hline Loop & $\begin{array}{c}\text { Disassembly } \\
\text { Remanufacturing } \\
\text { Recycling }\end{array}$ \\
\hline Virtualize & Smart services \\
\hline Exchange & Digital transformation \\
\hline
\end{tabular}

\subsection{Digital Technologies}

The largest shared classification for DTs, see for example [32,33], is the one proposed by Rüßmann et al. [14]. According to this classification, nine DTs can be identified (Figure 2):

- Internet of Things (IoT): technologies allowing the interaction, cooperation, collection and exchange of data among people, devices, things or objects through the use of modern wireless telecommunications [34];

- $\quad$ Big data analytics (BDA): information assets characterized by high volume, velocity and variety, requiring specific technology and analytical methods for being transformed into value [35]; 
- Cloud/fog/edge technologies (CLOUD): architectural models enabling pervasive, convenient and on-demand network access to shared resources such as networks or servers [36];

- Cybersecurity and blockchain (CYB): technologies, tools, guidelines and policies guaranteeing the protection of the cyber environment, allowing confidentiality, integrity and availability of data [37];

- Horizontal/Vertical system integration (HVSYS): universal data integration network, enabling an automated value chain within or among firms by means of linking products, plants, manufacturers, customers and suppliers [38];

- Simulation (SIM): a real-time reflection of the physical world (products, machines, human beings) in virtual models; it can allow testing and optimizing systems before implementing the physical change [31];

- Augmented reality (AR): technologies providing an interactive computer simulation, immersing the user in a programmed environment, simulating a sense of reality whether in the sight, in the hearing or the tactile sense [39];

- Autonomous robots (ROBs): robots able to operate completely autonomously, to interact with each other and to cooperate with human beings; sensors and control units facilitate the autonomous decision-making process and symbiotic work with humans [40];

- Additive manufacturing (AM): production of items directly from CAD models, with fabrication performed layering the material; $\mathrm{AM}$ offers the valuable ability to build parts with geometrical and material complexity, not feasible with traditional manufacturing processes [41].

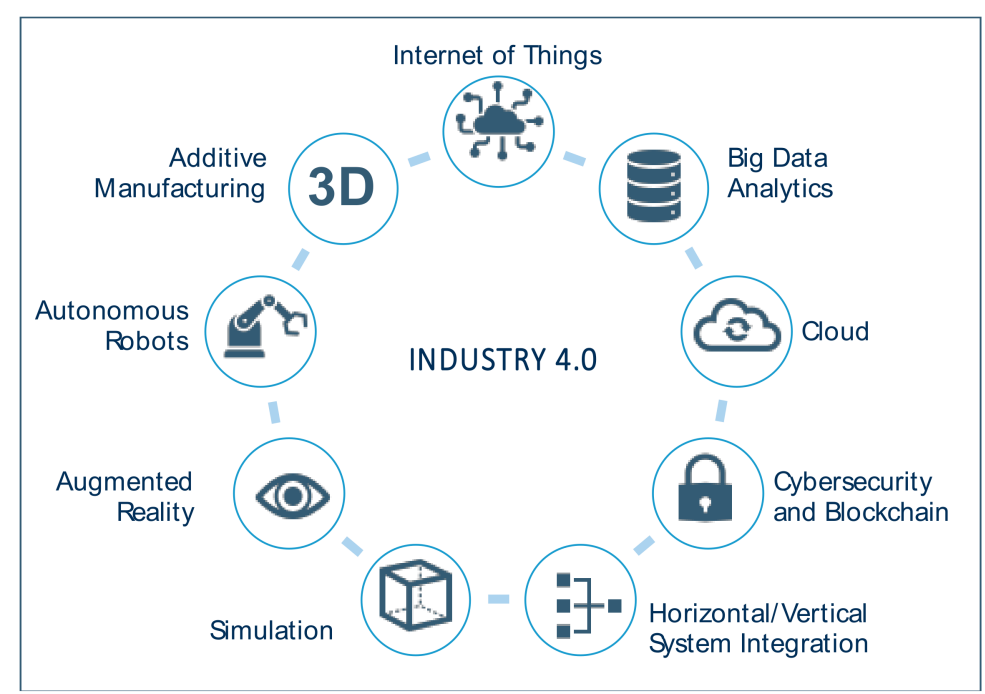

Figure 2. The nine Digital Technologies supporting Industry 4.0. Adapted from [14].

\section{Methods}

The present study employs a systematic literature review to identify, select and critically appraise relevant research. To guarantee a scientific and replicable approach, we referred to the steps proposed by Tranfield and Denyer [42], proceeding through (i) questions formulation, (ii) source identification, (iii) study selection and evaluation, (iv) analysis and synthesis and (v) reporting and using results. Additionally, to increase clarity and transparency, we used the Preferred Reporting Items for Systematic Reviews and Meta-Analyses (PRISMA)statement as the backbone of our analysis [43]. 


\subsection{Question Formulation}

We formulated the question according to the CIMO logic [42], combining a problematic context (C), for which the design proposition suggests a certain intervention (I), to produce, through specified generative mechanisms $(\mathrm{M})$, the intended outcome $(\mathrm{O})$ [44].

RQ: How (M) and in which condition (C) DTs (I) can enable the CE transition (O)?

\subsection{Source Identification}

For source identification, we investigated the Scopus database $[4,45,46]$. We performed a keyword-based search, interconnecting keywords deriving from the two paradigms, using terms related to CE (circular economy, circularity) and terms related to DTs (digital*, Industry 4.0, IoT, Internet of Things, Artificial Intelligence, AI) For the latter group of keywords, we selected the most frequent terms used in similar works [47,48]; additionally, we based our choice on the insights provided by Munirathinam [49] and Lee et al. [50], according to whom Internet of Things and Artificial Intelligence could be possibly used as synonymous of Industry 4.0. As for exclusion criteria, we limited the analysis to contributions published in English from the year 2000 onwards. We thus performed the following query: (TITLE-ABS-KEY ("circular economy") OR TITLE-ABS-KEY ("circularity")) AND (TITLE-ABS-KEY ("digital") OR TITLE-ABS-KEY ("industry 4.0") OR TITLE-ABS-KEY ("iot") OR TITLE-ABS-KEY ("internet of things") OR TITLE-ABS-KEY ("artificial intelligence") OR TITLE-ABS-KEY ("ai")) AND PUBYEAR > 1999 AND LIMIT-TO (LANGUAGE, "English"). The query led to 836 contributions (the search was first performed on 4 December 2020 and then updated on 11 February 2021). Figure 3 describes the steps followed in the selection/exclusion of contributions in the identification phase.

\subsection{Source Selection}

We proceeded with the selection of contributions according to the phases of the PRISMA methodology [51], namely screening, eligibility and inclusion (Figure 3). Concerning the screening, we aimed at discharging contributions (i) out of scope, addressing for example agriculture, construction, geometrical measurement or water; (ii) focusing only on CE; (iii) focusing only on DTs. Figure 3 describes the steps followed for the selection/exclusion of contributions in the screening, eligibility and inclusion phases. To avoid bias, all the phases were conducted autonomously by four reviewers; different results were confronted and discussed, reaching a common agreement. Based on [52,53], we then applied the snowball method, identifying three additional contributions; the contributions were not previously identified as (i) not available on Scopus on the date the last update was performed $(n=1)$ [54]; (ii) employing specific keywords not included in our query $(n=2)[4,55]$. 


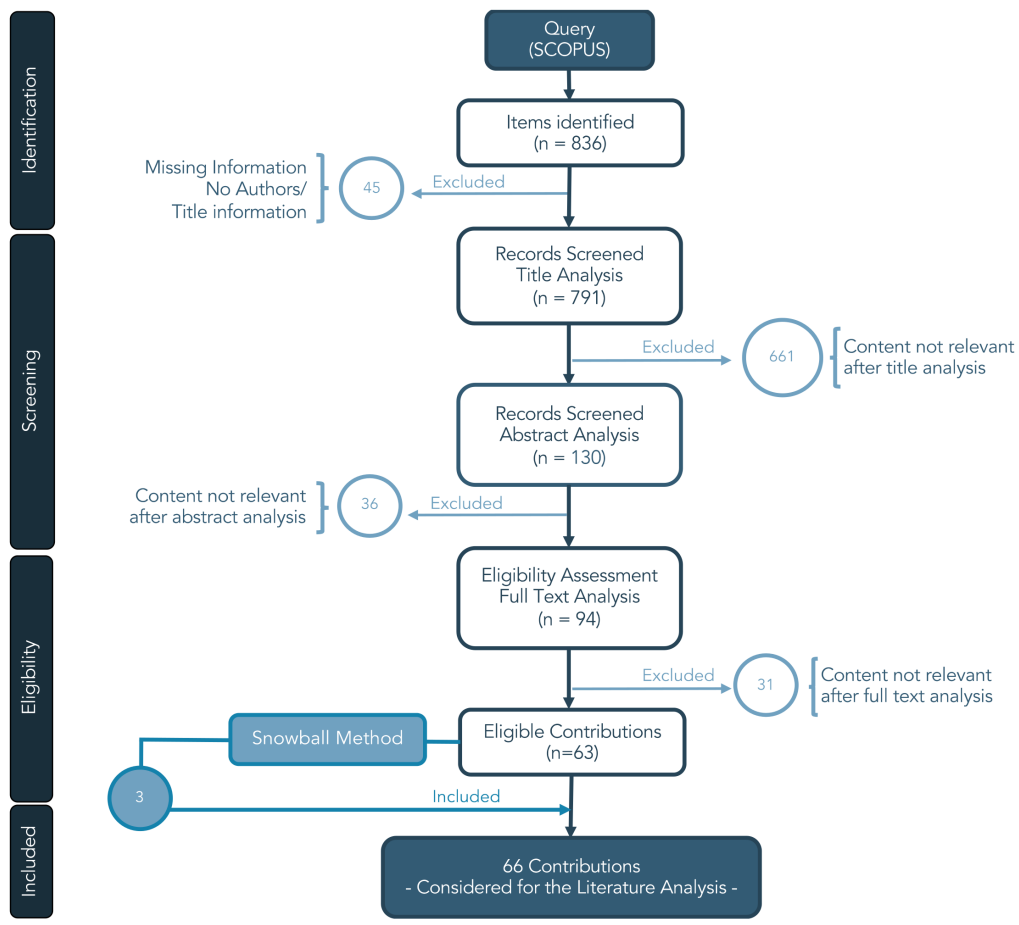

Figure 3. Preferred Reporting Items for Systematic Reviews and Meta-Analyses (PRISMA) methodology. The figure reports the different phases of the PRISMA methodology.

The retrieved contributions were classified according to critical dimensions of analysis (Table 2): general information (author; year of publication; journal; document type); bibliometric information (global citations score (GCS) - as by February 11th, 2021; GCS divided by the number of years since publication); content (CE aspects; DTs; type of study; empirical methodology); context (geographical area; sector; size)—see also [56-58]. Based on the discussion provided in Section 2.1, the CE aspects considered were general, ReSOLVE, CBM, DIGIT, DISAS, LIFEC, RECYC, REMAN, RESOU, REUSE, SMSER and SCM. Based on the discussion provided in Section 2.2, the DTs considered were general, IOT, BDA, CLOUD, CYB, HVSYS, SIM, AR, ROB and AM.

\subsection{Data Analysis, Reporting and Using of Results}

A critical analysis of the retrieved contributions paves the road to a discussion of the data, identifying key messages and areas for which further additional research is necessary [56]. The appraisal was conducted through a descriptive analysis of the results (Section 4) and an evaluation of emerging themes (Section 5). The results deriving from the two analyses are integrated into an overall discussion (Section 6). 


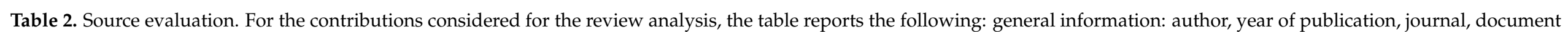

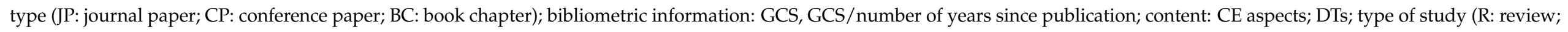

C: conceptual; E: empirical); empirical methodology; context: geographical area, sector, size.

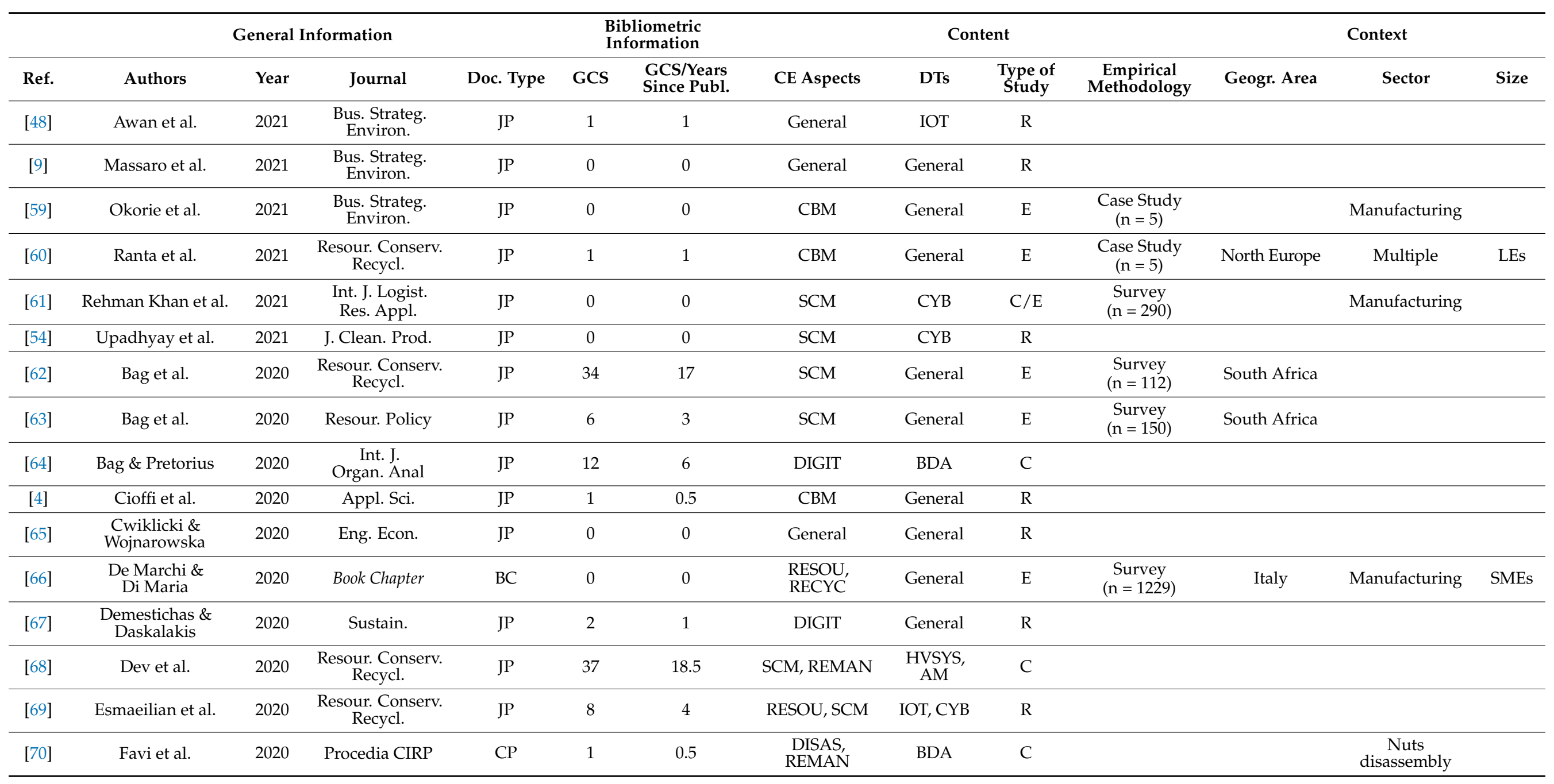


Table 2. Cont.

\begin{tabular}{|c|c|c|c|c|c|c|c|c|c|c|c|c|c|}
\hline \multirow[b]{2}{*}{ Ref. } & \multicolumn{4}{|c|}{ General Information } & \multicolumn{2}{|c|}{$\begin{array}{l}\text { Bibliometric } \\
\text { Information }\end{array}$} & \multicolumn{4}{|c|}{ Content } & \multicolumn{3}{|c|}{ Context } \\
\hline & Authors & Year & Journal & Doc. Type & GCS & $\begin{array}{l}\text { GCS/Years } \\
\text { Since Publ. }\end{array}$ & CE Aspects & DTs & $\begin{array}{l}\text { Type of } \\
\text { Study }\end{array}$ & $\begin{array}{c}\text { Empirical } \\
\text { Methodology }\end{array}$ & Geogr. Area & Sector & Size \\
\hline [71] & Getor et al. & 2020 & $\begin{array}{c}\text { Resour. Conserv. } \\
\text { Recycl. }\end{array}$ & JP & 0 & 0 & RECYC & BDA & $\mathrm{C}$ & & & Plastic waste & \\
\hline [72] & $\begin{array}{l}\text { Ghoreishi \& } \\
\text { Happonen }\end{array}$ & 2020 & $\begin{array}{l}\text { Conference } \\
\text { Proceedings }\end{array}$ & $\mathrm{CP}$ & 2 & 1 & CBM & BDA & $\mathrm{C} / \mathrm{E}$ & $\begin{array}{l}\text { Case Study } \\
(\mathrm{n}=3)\end{array}$ & Finland & Manufacturing & LEs \\
\hline [15] & $\begin{array}{l}\text { Ghoreishi \& } \\
\text { Happonen }\end{array}$ & 2020 & $\begin{array}{l}\text { Conference } \\
\text { Proceedings }\end{array}$ & $\mathrm{CP}$ & 3 & 1.5 & ReSOLVE & $\begin{array}{c}\text { IOT, } \\
\text { BDA, } \\
\text { CLOUD, } \\
\text { AM }\end{array}$ & $\mathrm{R}$ & & & & \\
\hline [73] & Ingemarsdotter et al. & 2020 & $\begin{array}{c}\text { Resour. Conserv. } \\
\text { Recycl. }\end{array}$ & JP & 5 & 2.5 & $\mathrm{CBM}$ & IOT & $\mathrm{E}$ & $\begin{array}{l}\text { Case Study } \\
(\mathrm{n}=1)\end{array}$ & Europe & LED lighting & LEs \\
\hline [74] & Kintscher et al. & 2020 & J. Commun. & JP & 0 & 0 & RECYC & General & $\mathrm{C} / \mathrm{E}$ & $\begin{array}{l}\text { Example } \\
\text { from Lit. }\end{array}$ & & Electric vehicle & \\
\hline [75] & Kouhizadeh et al. & 2020 & $\begin{array}{l}\text { Prod. Plan. } \\
\text { Control }\end{array}$ & JP & 21 & 10.5 & ReSOLVE & CYB & $\mathrm{C}$ & $\begin{array}{l}\text { Example } \\
\text { from Lit. }\end{array}$ & & & \\
\hline$[76]$ & Kravchenko et al. & 2020 & $\begin{array}{l}\text { Conference } \\
\text { Proceedings }\end{array}$ & $\mathrm{CP}$ & 0 & 0 & DIGIT & $\mathrm{AM}$ & $\mathrm{C}$ & & & & \\
\hline [78] & Mboli et al. & 2020 & $\begin{array}{l}\text { Conference } \\
\text { Proceedings }\end{array}$ & $\mathrm{CP}$ & 2 & 1 & $\mathrm{SCM}$ & IOT & $\mathrm{C} / \mathrm{E}$ & $\begin{array}{l}\text { Case Study } \\
(\mathrm{n}=1)\end{array}$ & & $\begin{array}{l}\text { Coffee machine } \\
\text { manufacturing }\end{array}$ & LEs \\
\hline [79] & Moller & 2020 & $\begin{array}{l}\text { Conference } \\
\text { Proceedings }\end{array}$ & $\mathrm{CP}$ & 0 & 0 & DIGIT & General & $\mathrm{C}$ & & & & \\
\hline$[80]$ & Nobre \& Tavares & 2020 & $\begin{array}{l}\text { Johnson Matthey } \\
\text { Technol. Rev. }\end{array}$ & JP & 3 & 1.5 & ReSOLVE & $\begin{array}{l}\text { IOT, } \\
\text { BDA }\end{array}$ & $\mathrm{R}$ & & & & \\
\hline$[81]$ & Nobre \& Tavares & 2020 & $\begin{array}{l}\text { Johnson Matthey } \\
\text { Technol. Rev. }\end{array}$ & JP & 2 & 1 & ReSOLVE & $\begin{array}{l}\text { IOT, } \\
\text { BDA }\end{array}$ & $\mathrm{R}$ & & & & \\
\hline [82] & Piscitelli et al. & 2020 & Procedia Manuf. & $\mathrm{CP}$ & 2 & 1 & CBM & General & $\mathrm{R}$ & & & & \\
\hline [83] & Poschmann et al. & 2020 & Chemie Ing. Tech & JP & 3 & 1.5 & DISAS & ROB & $\mathrm{R}$ & & & & \\
\hline$[84]$ & Rajput \& Singh & 2020 & J. Clean. Prod. & JP & 2 & 1 & DIGIT & General & $\mathrm{C}$ & & & & \\
\hline$[85]$ & Rocca et al. & 2020 & Sustain. & JP & 8 & 4 & DISAS & $\begin{array}{l}\text { SIM, AR, } \\
\text { ROB }\end{array}$ & $\mathrm{E}$ & Modelling & & WEEE & \\
\hline$[31]$ & Rosa et al. & 2020 & Int. J. Prod. Res. & $\mathrm{JP}$ & 41 & 20.5 & General & General & $\mathrm{R}$ & & & & \\
\hline
\end{tabular}


Table 2. Cont.

\begin{tabular}{|c|c|c|c|c|c|c|c|c|c|c|c|c|c|}
\hline \multirow[b]{2}{*}{ Ref. } & \multicolumn{4}{|c|}{ General Information } & \multicolumn{2}{|c|}{$\begin{array}{l}\text { Bibliometric } \\
\text { Information }\end{array}$} & \multicolumn{4}{|c|}{ Content } & \multicolumn{3}{|c|}{ Context } \\
\hline & Authors & Year & Journal & Doc. Type & GCS & $\begin{array}{l}\text { GCS/Years } \\
\text { Since Publ. }\end{array}$ & CE Aspects & DTs & $\begin{array}{l}\text { Type of } \\
\text { Study }\end{array}$ & $\begin{array}{c}\text { Empirical } \\
\text { Methodology }\end{array}$ & Geogr. Area & Sector & Size \\
\hline [86] & Rossi et al. & 2020 & Sustain. & $\mathrm{JP}$ & 3 & 1.5 & $\mathrm{CBM}$ & General & $\mathrm{C} / \mathrm{E}$ & $\begin{array}{l}\text { Example } \\
\text { from Lit. }\end{array}$ & Europe & Manufacturing & LEs \\
\hline [87] & Uçar et al. & 2020 & Procedia CIRP & $\mathrm{CP}$ & 2 & 1 & $\mathrm{CBM}$ & $\begin{array}{c}\text { IOT, } \\
\text { BDA, } \\
\text { CLOUD }\end{array}$ & $\mathrm{E}$ & $\begin{array}{l}\text { Case Study } \\
(\mathrm{n}=3)\end{array}$ & Europe & Multiple & \\
\hline$[88]$ & Yadav et al. & 2020 & J. Clean. Prod. & $\mathrm{JP}$ & 40 & 20 & $\mathrm{SCM}$ & General & $\mathrm{C} / \mathrm{E}$ & Experts & & Automotive & \\
\hline [89] & Alcayaga et al. & 2019 & J. Clean. Prod. & $\mathrm{JP}$ & 30 & 10 & $\begin{array}{c}\text { LIFEC, REUSE, } \\
\text { REMAN, } \\
\text { RECYC, } \\
\text { SMSER }\end{array}$ & $\begin{array}{l}\text { IOT, } \\
\text { BDA }\end{array}$ & $\mathrm{R}$ & & & & \\
\hline$[90]$ & Cezarino et al. & 2019 & Manag. Decis. & $\mathrm{JP}$ & 15 & 5 & DIGIT & General & $\mathrm{C}$ & & $\begin{array}{l}\text { Emerging } \\
\text { economies }\end{array}$ & & \\
\hline$[55]$ & $\begin{array}{c}\text { Chiappetta } \\
\text { Jabbour et al. }\end{array}$ & 2019 & $\begin{array}{l}\text { Technol. } \\
\text { Forecast. Soc. } \\
\text { Change }\end{array}$ & $\mathrm{JP}$ & 72 & 24 & ReSOLVE & BDA & C & & & & \\
\hline [91] & Charnley et al. & 2019 & Sustain. & $\mathrm{JP}$ & 11 & 3.67 & REMAN & SIM & $\mathrm{E}$ & & UK & Automotive & LEs \\
\hline [92] & Garcia-Muiña et al. & 2019 & Soc. Sci. & $\mathrm{JP}$ & 24 & 8 & RESOU & IOT & $\mathrm{E}$ & $\begin{array}{c}\text { Case Study } \\
(\mathrm{n}=10)\end{array}$ & Italy & Ceramic & \\
\hline [93] & Garrido-Hidalgo et al. & 2019 & Comp. Ind. & $\mathrm{JP}$ & 14 & 4.67 & $\mathrm{SCM}$ & $\begin{array}{c}\text { IOT, } \\
\text { CLOUD }\end{array}$ & $\mathrm{E}$ & $\begin{array}{c}\text { Case Study } \\
(\mathrm{n}=1)\end{array}$ & & WEEE & \\
\hline [94] & Gligoric et al. & 2019 & Sensors & $\mathrm{JP}$ & 11 & 3.67 & LIFEC & IOT & $\mathrm{C} / \mathrm{E}$ & Modelling & Austria & Manufacturing & \\
\hline [95] & Ingemarsdotter et al. & 2019 & Sustain. & $\mathrm{JP}$ & 8 & 2.67 & $\begin{array}{c}\text { CBM, LIFEC, } \\
\text { REUSE, } \\
\text { RESOU, } \\
\text { REMAN }\end{array}$ & IOT & C & $\begin{array}{l}\text { Example } \\
\text { from Lit. }\end{array}$ & & & \\
\hline [96] & Kerin \& Pham & 2019 & J. Clean. Prod. & $\mathrm{JP}$ & 41 & 13.67 & $\begin{array}{l}\text { DISAS, } \\
\text { REMAN }\end{array}$ & $\begin{array}{c}\text { AM, IOT, } \\
\text { AR }\end{array}$ & $\mathrm{R}$ & & & & \\
\hline [97] & Moreno et al. & 2019 & $\begin{array}{l}\text { Smart Innov. } \\
\text { Syst. Technol. }\end{array}$ & $\mathrm{JP}$ & 9 & 3 & $\mathrm{SCM}$ & General & $\mathrm{E}$ & $\begin{array}{c}\text { Case Study } \\
(\mathrm{n}=3)\end{array}$ & UK & Manufacturing & LEs \\
\hline [98] & Nascimento et al. & 2019 & $\begin{array}{c}\text { J. Manuf. } \\
\text { Technol. Manag. }\end{array}$ & $\mathrm{JP}$ & 99 & 33 & $\mathrm{CBM}$ & IOT, AM & C & & & & \\
\hline [99] & Pham et al. & 2019 & Sustain. & JP & 17 & 5.67 & SMSER & $\begin{array}{c}\text { IOT, } \\
\text { CLOUD }\end{array}$ & $\mathrm{E}$ & $\begin{array}{l}\text { Case Study } \\
(\mathrm{n}=1)\end{array}$ & Taiwan & Electric vehicle & \\
\hline
\end{tabular}


Table 2. Cont.

\begin{tabular}{|c|c|c|c|c|c|c|c|c|c|c|c|c|c|}
\hline \multirow[b]{2}{*}{ Ref. } & \multicolumn{4}{|c|}{ General Information } & \multicolumn{2}{|c|}{$\begin{array}{l}\text { Bibliometric } \\
\text { Information }\end{array}$} & \multicolumn{4}{|c|}{ Content } & \multicolumn{3}{|c|}{ Context } \\
\hline & Authors & Year & Journal & Doc. Type & GCS & $\begin{array}{l}\text { GCS/Years } \\
\text { Since Publ. }\end{array}$ & CE Aspects & DTs & $\begin{array}{c}\text { Type of } \\
\text { Study }\end{array}$ & $\begin{array}{c}\text { Empirical } \\
\text { Methodology }\end{array}$ & Geogr. Area & Sector & Size \\
\hline$[100]$ & Rajput \& Singh & 2019 & $\begin{array}{c}\text { Benchmarking } \\
\text { An Int. J. }\end{array}$ & $\mathrm{JP}$ & 59 & 19.67 & DIGIT & General & $\mathrm{C}$ & & & & \\
\hline [101] & Rajput \& Singh & 2019 & $\begin{array}{l}\text { Int. J. Inf. } \\
\text { Manage. }\end{array}$ & JP & 22 & 7.33 & SCM & General & $\mathrm{E}$ & $\begin{array}{c}\text { Survey } \\
(\mathrm{n}=161)\end{array}$ & & & \\
\hline [102] & Riesener et al. & 2019 & $\begin{array}{c}\text { Conference } \\
\text { Proceedings }\end{array}$ & $\mathrm{CP}$ & 0 & 0 & LIFEC & General & C & & & & \\
\hline [103] & Sarc et al. & 2019 & Waste Manag. & JP & 28 & 9.33 & RECYC & IOT, ROB & $\mathrm{R}$ & & & $\begin{array}{c}\text { Waste } \\
\text { management }\end{array}$ & \\
\hline [104] & Väisänen et al. & 2019 & $\begin{array}{l}\text { Conference } \\
\text { Proceedings }\end{array}$ & $\mathrm{CP}$ & 0 & 0 & DIGIT & General & C & & & & \\
\hline$[13]$ & Antikainen et al. & 2018 & Procedia CIRP & $\mathrm{CP}$ & 44 & 11 & CBM & General & $\mathrm{E}$ & Experts & & & \\
\hline [105] & Bianchini et al. & 2018 & $\begin{array}{l}\text { Conference } \\
\text { Proceedings }\end{array}$ & $\mathrm{CP}$ & 6 & 1.5 & $\begin{array}{c}\text { LIFEC, } \\
\text { RESOU, } \\
\text { SMSER, DIGIT }\end{array}$ & General & $\mathrm{C} / \mathrm{E}$ & $\begin{array}{l}\text { Example } \\
\text { from Lit. }\end{array}$ & & Manufacturing & \\
\hline [106] & Bressanelli et al. & 2018 & Sustain. & JP & 94 & 23.5 & CBM & $\begin{array}{l}\text { IOT, } \\
\text { BDA }\end{array}$ & E & $\begin{array}{c}\text { Case Study } \\
(\mathrm{n}=1)\end{array}$ & Italy & $\begin{array}{c}\text { Household } \\
\text { appliances }\end{array}$ & SMEs \\
\hline$[17]$ & $\begin{array}{c}\text { Lopes de Sousa } \\
\text { Jabbour et al. }\end{array}$ & 2018 & Ann. Oper. Res. & JP & 183 & 45.75 & ReSOLVE & $\begin{array}{l}\text { IOT, } \\
\text { CLOUD, } \\
\text { AM }\end{array}$ & C & & & & \\
\hline [108] & Makarova et al. & 2018 & $\begin{array}{c}\text { Conference } \\
\text { Proceedings }\end{array}$ & $\mathrm{CP}$ & 0 & 0 & SCM & $\begin{array}{c}\text { BDA, } \\
\text { HVSYS }\end{array}$ & $\mathrm{C}$ & & & Automotive & LEs \\
\hline [109] & Neligan & 2018 & Intereconomics & $\mathrm{JP}$ & 10 & 2.5 & RESOU & General & E & $\begin{array}{l}\text { Survey } \\
(\mathrm{n}=600)\end{array}$ & Germany & Manufacturing & $\begin{array}{l}\text { SME; } \\
\text { LEs }\end{array}$ \\
\hline$[21]$ & Okorie et al. & 2018 & Energies & JP & 27 & 6.75 & General & General & $\mathrm{R}$ & & & & \\
\hline$[16]$ & Nobre \& Tavares & 2017 & Scientometrics & JP & 99 & 19.8 & DIGIT & $\begin{array}{l}\text { IOT, } \\
\text { BDA }\end{array}$ & $\mathrm{R}$ & & & & \\
\hline [110] & Pagoropoulos et al. & 2017 & Procedia CIRP & $\mathrm{CP}$ & 73 & 14.6 & DIGIT & General & $\mathrm{R}$ & & & & \\
\hline [111] & Moreno \& Charnley & 2016 & $\begin{array}{l}\text { Conference } \\
\text { Proceedings }\end{array}$ & $\mathrm{CP}$ & 27 & 4.5 & DIGIT & General & $\mathrm{C} / \mathrm{E}$ & $\begin{array}{l}\text { Example } \\
\text { from Lit. }\end{array}$ & & Manufacturing & \\
\hline [112] & Reuter & 2016 & $\begin{array}{l}\text { Metall. Mater. } \\
\text { Trans. B }\end{array}$ & JP & 37 & 6.17 & RESOU, DIGIT & $\begin{array}{l}\text { IOT, } \\
\text { BDA }\end{array}$ & C & & Germany & Metallurgy & \\
\hline
\end{tabular}




\section{Digital Technologies Enabling the CE Transition: Descriptive Analysis of Results} 4.1. Analysis of General Information

The temporal distribution of the contributions shows a more than linear growth, with $85 \%$ of them $(n=53)$ published from 2019 on, highlighting an increasing interest (Figure 4).

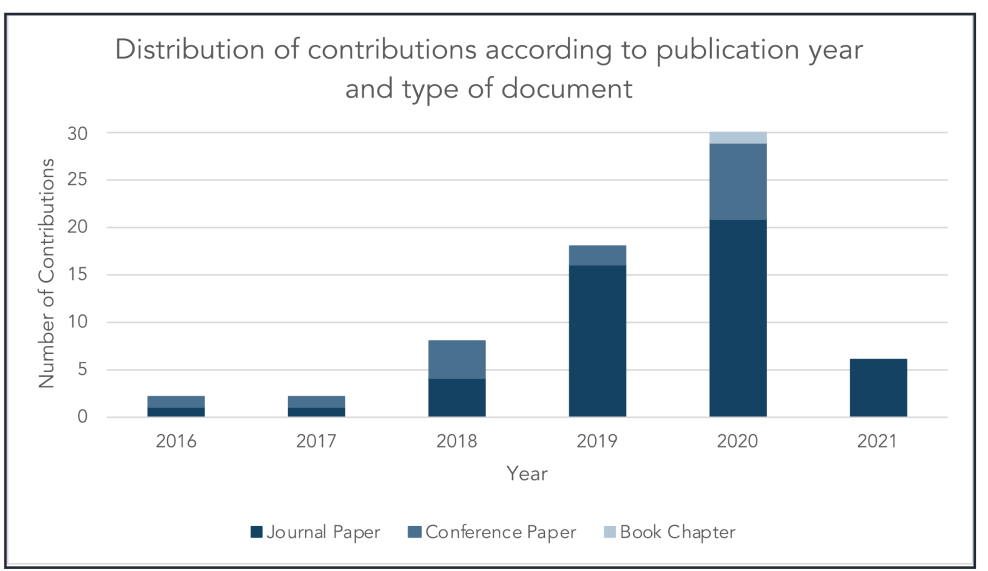

Figure 4. Distribution of the reviewed contributions according to publication year and type of document.

Considering the journal papers, the most recurrent Journals are Sustainability (Switzerland) $(n=7)$ and Resources, Conservations and Recycling $(n=6)$. The distribution shows how the topic has been mainly addressed by sources at the intersection of management- and environment-related areas (Figure 5).

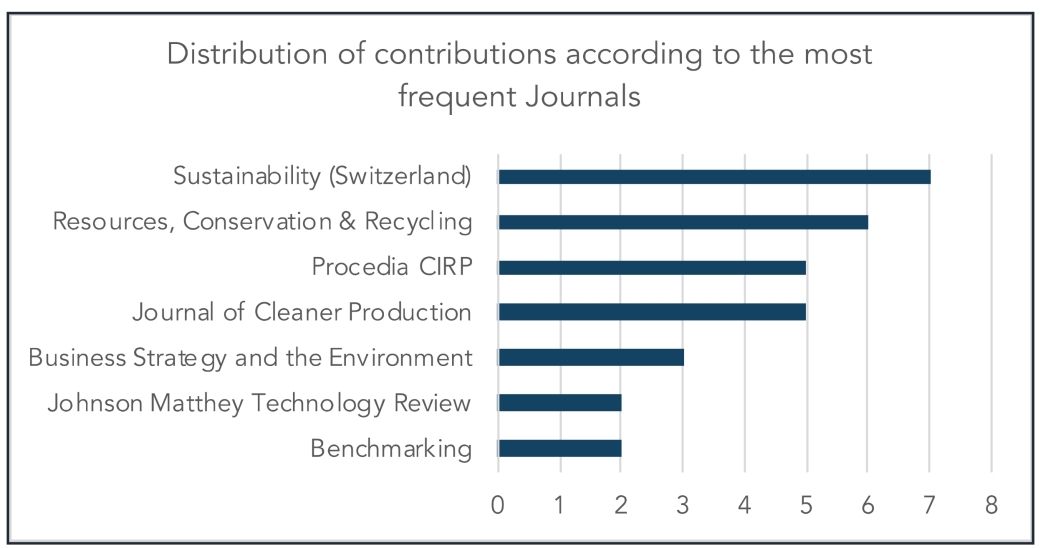

Figure 5. Distribution of the reviewed contributions according to the most frequent journals.

In terms of authorship, 188 different authors were identified; $82 \%$ of the authors $(n=154)$ participated in the discourse with 1 contribution, and $16 \%(n=30)$ with 2 contributions. Nine authors contributed with 3 (Bag S.; Nobre G.C.; Okorie O.; Rajput S.; Singh S.P.; Tavares E.; Tiwari A.) or 5 contributions (Charnley F. Moreno M.) (Figure 6). The affiliations were in the United Kingdom (Charnley F., Moreno M. and Okorie O, Cranfield University until 2019, then University of Exeter; Okorie O. University of Sheffield until 2019, then University of Exeter), South Africa (Bag. S., University of Johannesburg), India (Rajput S. and Singh S.P., Indian Institute of Technology) and Brazil (Nobre G.C.; Tavares E., Federal University of Rio De Janeiro). 


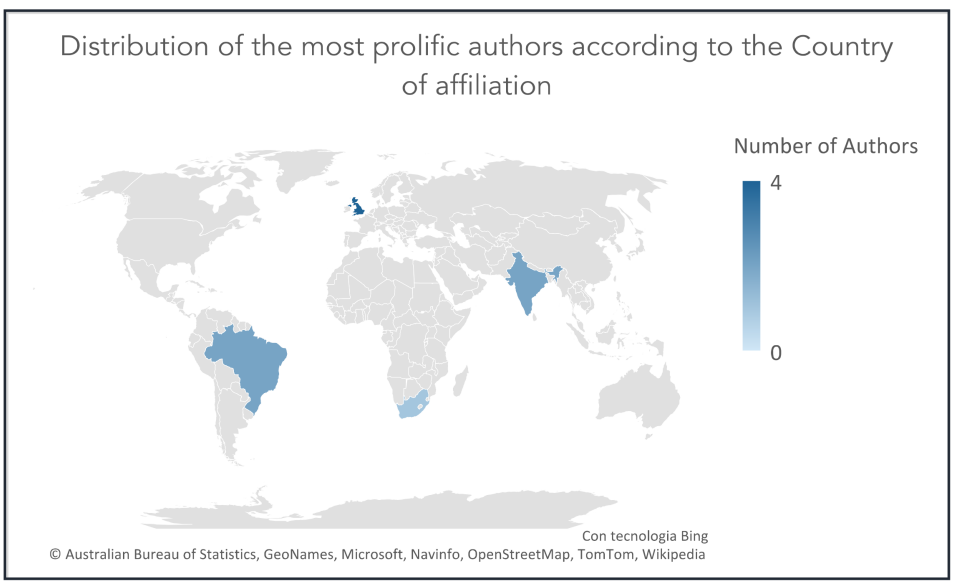

Figure 6. Distribution of the most prolific authors according to the country of affiliation.

\subsection{Analysis of Bibliographic Information}

As for the impact of the contributions, the highest GCS were 183 [17], 99 [16,98] and 94 [106]. The average GCS was about 21 , and $89 \%$ of contributions received so far less than 50 citations. The GCS was divided by the number of years since publication to better appreciate the breakthrough literature. The highest scores were 146 [17], 33 [98] and 24 citations/year [55]. The average score was almost 7, and $79 \%$ of contributions received so far less than 10 citations/year. As the first ten contributions according to both the analyses were almost overlapping, the second analysis pinpoints the breakthrough potential of specific conceptual works $[55,98]$ and particularly of the empirical ones by Yadav et al. [113] and Bag et al. [62] (Figure 7). However, numerous contributions from 2020 to 2021 received so far 0 citations, so the list of breakthrough contributions might change in a short time.

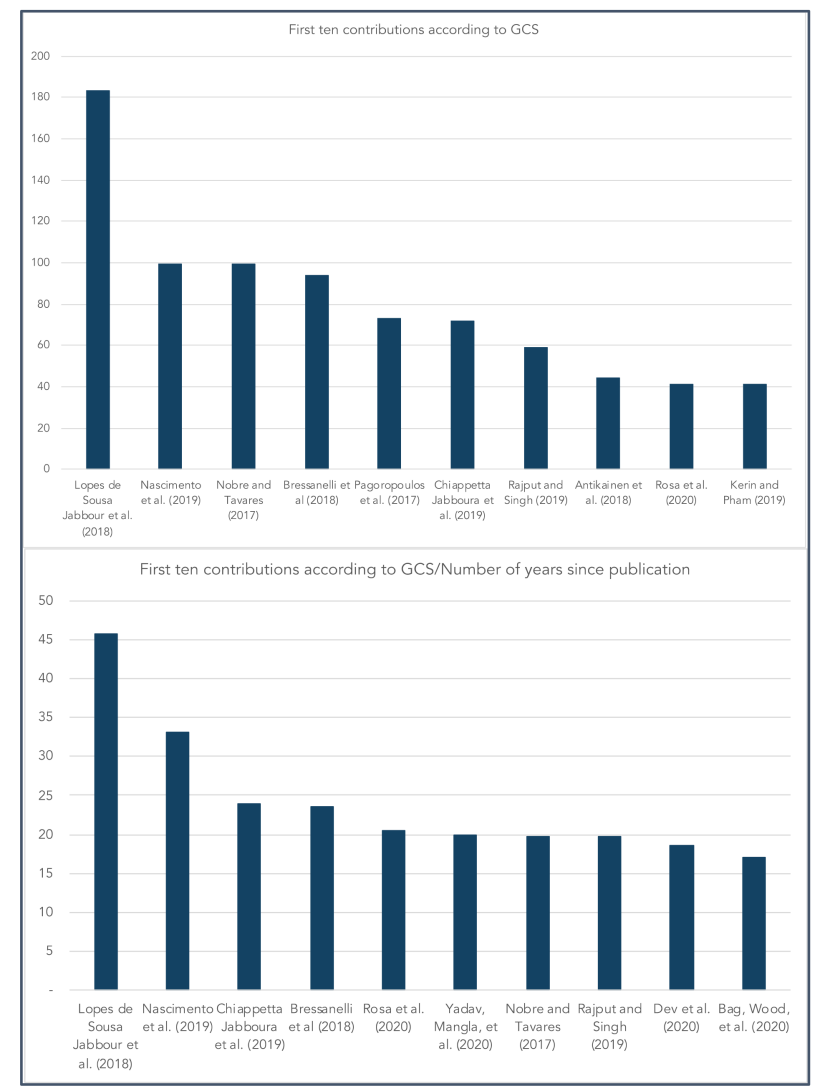

Figure 7. First ten contributions according to GCS and GCS/number of years after publication. 


\subsection{Analysis of Content}

The most discussed CE aspects were related to CBM, SCM and DIGIT, while among the least discussed, REUSE and SMSER can be identified (Figure 8). Referring to the ReSOLVE areas, the main addressed ones were exchange and optimize, while among the least discussed, virtualize and share can be identified (Figure 8). As for DTs, the discourse was led by a general perspective on DTs. The most considered single DTs were IoT and DBA; nonetheless, the two of them were strongly interrelated, as IoT can be fully exploited only if the data collected are then processed with BDA [114] (Figure 9).

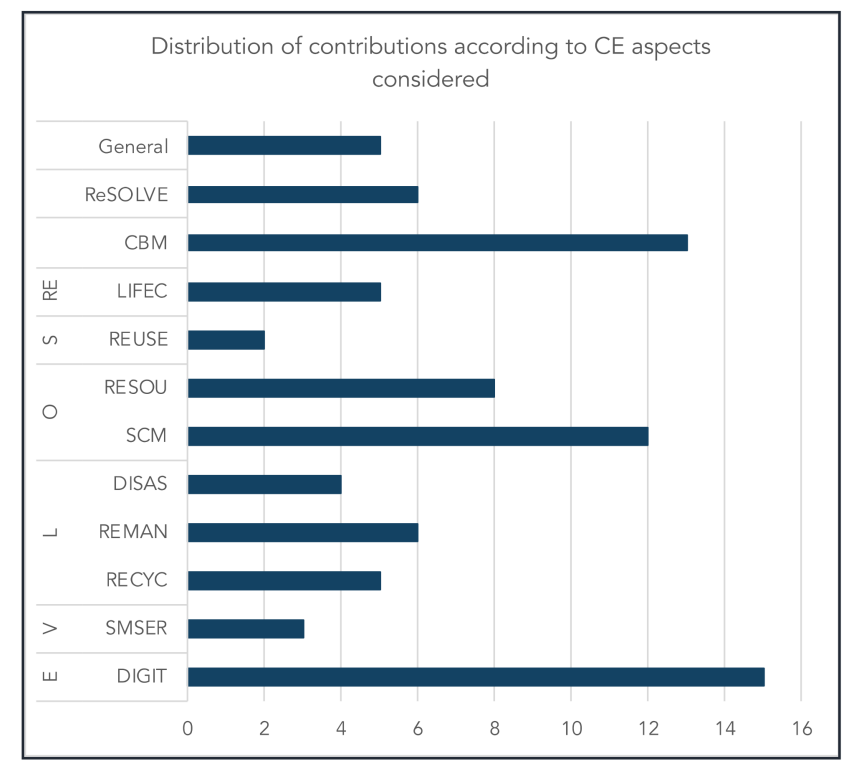

Figure 8. Distribution of the reviewed contributions according to $\mathrm{CE}$ aspects considered.

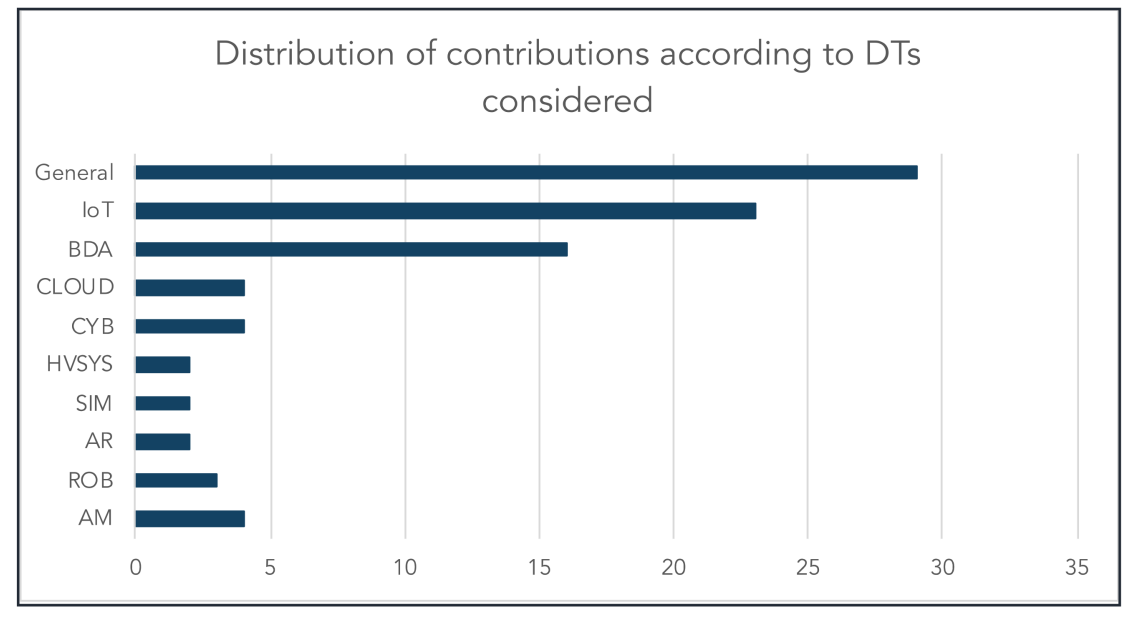

Figure 9. Distribution of the reviewed contributions according to DTs considered.

The integrated analysis of the two paradigms, considering how CE aspects and DTs have been integrated, offers sparks for further discussions (Figure 10): SCM was linked to the highest number of DTs and CYB particularly; DISAS and REMAN were linked with SIM and AR; DIGIT has been addressed from a general perspective in terms of DTs. Additionally, the literature has so far considered the impact of more DTs for the optimize and loop areas, compared to the other areas. Details on the specific relationship will be discussed in Section 5.1. 


\begin{tabular}{|c|c|c|c|c|c|c|c|c|c|c|c|}
\hline & \multicolumn{10}{|c|}{ Digital Tecnologies } \\
\hline & & General & loT & BDA & CLOUD & CYB & HVSYS & SIM & $A R$ & $\mathrm{ROB}$ & $A M$ \\
\hline \multirow{7}{*}{ 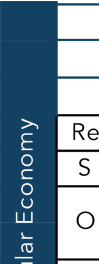 } & General & 1 & 1 & & & & & & & & \\
\hline & CBM & 6 & 6 & 5 & 1 & & & & & & 1 \\
\hline & ReSOLVE & & 4 & 3 & 2 & 1 & & & & & 2 \\
\hline & LIFEC & 2 & 3 & 1 & & & & & & & \\
\hline & REUSE & & 2 & 1 & & & & & & & \\
\hline & RESOU & 4 & 4 & 1 & & 1 & & & & & \\
\hline & $\mathrm{SCM}$ & 5 & 3 & 1 & 1 & 3 & 2 & & & & 1 \\
\hline \multirow{3}{*}{ L } & DISAS & & 1 & 1 & & & & 1 & 2 & 2 & 1 \\
\hline & REMAN & & 3 & 2 & & & 1 & 1 & 1 & & 2 \\
\hline & RECYC & 2 & 2 & 2 & & & & & & 1 & \\
\hline $\mathrm{V}$ & SMSER & 1 & 2 & 1 & 1 & & & & & & \\
\hline $\mathrm{E}$ & DIGIT & 10 & 3 & 4 & & & & & & & 1 \\
\hline
\end{tabular}

Figure 10. Heatmap of the distribution of the reviewed contributions according to CE aspects and DTs considered.

In terms of the type of study, $58 \%$ of contributions were theoretical, both review $(n=19)$ or conceptual papers $(n=20)$; the remaining share was either empirical $(n=18)$ or theoretical with a following empirical application $(n=9)$ (Figure 11).

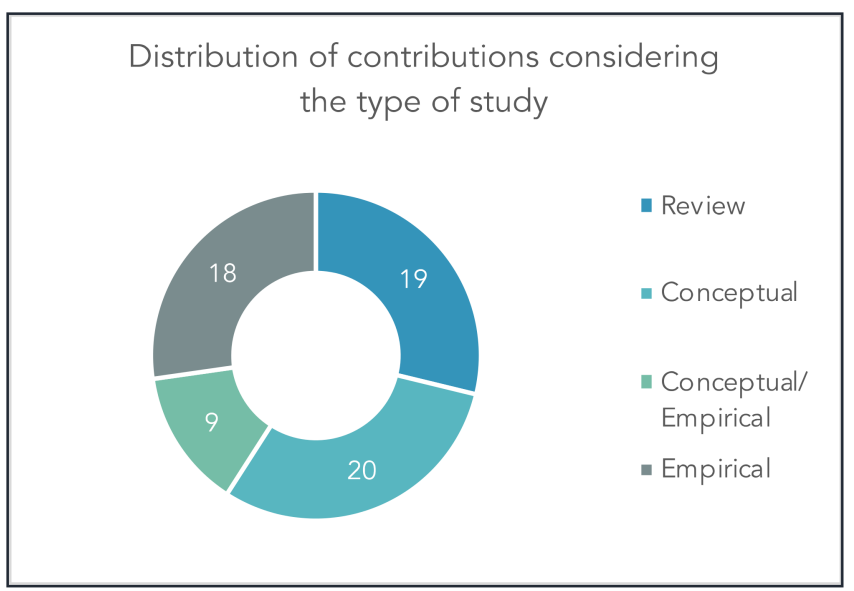

Figure 11. Distribution of the reviewed contributions according to the type of study.

Focusing on the methodology for empirical application (Figure 12), 43\% of the contributions $(n=12)$ employed the case study methodology, followed by surveys or expert opinions. Interestingly, none of the contributions conducted more than 10 case studies, as the majority conducted $1(n=6)$ or $3(n=3)$ case studies.

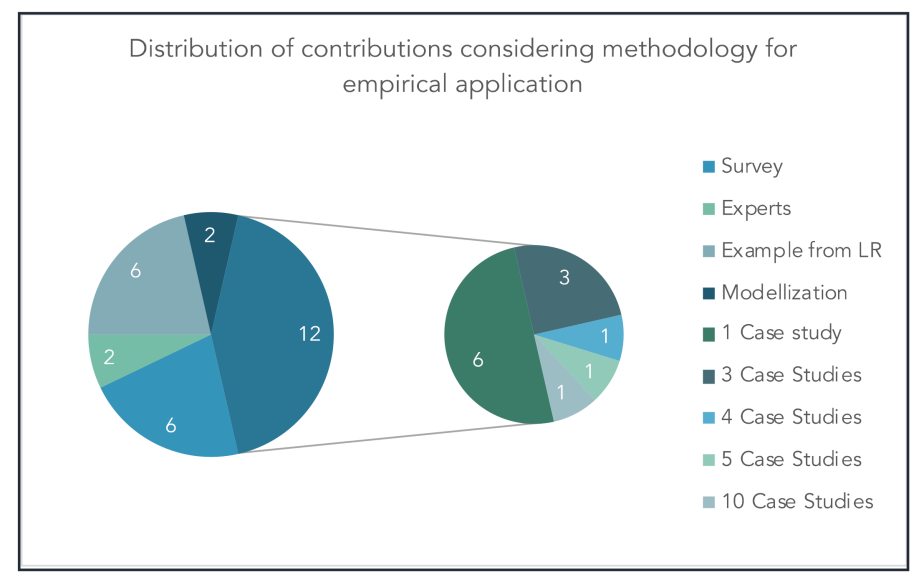

Figure 12. Distribution of the reviewed contributions according to the methodology employed for the empirical application. 


\subsection{Analysis of Context}

Few contributions considered a specific context. In terms of geographical area, only $28 \%$ of contributions considered a specific one $(n=18)$, with a predominance of European countries $(\mathrm{n}=14)$. As for the sector, $55 \%$ of contributions addressed a specific sector $(n=29)$, and most of them focused on the manufacturing sector in general. As for the size of firms, very few contributions considered a specific one, with $82 \%$ of contributions not providing any information. Some contributions nonetheless addressed specifically small and medium enterprises (SMEs) $(n=8)$, large enterprises $(\mathrm{LEs})(n=3)$ or both $(n=1)$.

\section{Digital Technologies Enabling the CE Transition: Emerging Themes}

This section discusses the qualitative findings deriving from the literature review, according to the guidelines provided in Table 1 and addressing the role of DTs in enabling the ReSOLVE framework. Although the relationship between DTs and the CE has been largely investigated, and specific connections have emerged, a general complete overview of the relations between the two topics has not been reached yet (Figure 10) $[13,17]$. Nonetheless, interesting points have emerged, starting from a consensus that DTs can act as an enabler for CE.

An in-depth analysis of the insights deriving from the reviewed contributions is offered in Table 3. Each contribution is analyzed according to context and motivation, main contribution, main findings, main limitations and main future research. The analysis provides an overview of the different application areas and outcomes of the extant literature; it is followed by an integrated presentation of the results according to the DTs' potentials in operationalizing the $\mathrm{CE}$ transition.

Table 3. In-depth analysis of the content. For the contributions considered for the review analysis, the table reports the following: context and motivation, main contribution, main findings, main limitations and main future research. Limitations in italic refer to limitations related to the specific aim of the present study according to the authors' perspective.

\begin{tabular}{|c|c|c|c|c|c|c|}
\hline Ref. & Authors & $\begin{array}{l}\text { Context and } \\
\text { Motivation }\end{array}$ & Main Contribution & Main Findings & Main Limitations & $\begin{array}{l}\text { Main Future } \\
\text { Research }\end{array}$ \\
\hline$[48]$ & Awan et al. & $\begin{array}{c}\text { I4.0 and CE pose } \\
\text { risks and } \\
\text { opportunities } \\
\text { to various } \\
\text { stakeholders, } \\
\text { whose interests and } \\
\text { expectations should } \\
\text { be understood. }\end{array}$ & $\begin{array}{l}\text { Literature review to } \\
\text { identify stakeholders' } \\
\text { interests and } \\
\text { expectations on how } \\
\text { I4.0 can be part of } \\
\text { CE transition. }\end{array}$ & $\begin{array}{l}\text { The stakeholders' interests } \\
\text { and expectations are a } \\
\text { reference point to start a } \\
\text { discussion toward I4.0 } \\
\text { and CE integration and to } \\
\text { shape an organization's } \\
\text { strategy for stakeholder } \\
\text { orientations. }\end{array}$ & $\begin{array}{l}\text { Systematic protocol } \\
\text { limitations (timespan). } \\
\text { No focus on specific } \\
\text { aspects of the DTs and } \\
\text { CE relationship; } \\
\text { no focus on } \\
\text { operationalization. }\end{array}$ & $\begin{array}{c}\text { Need for empirical } \\
\text { research on I4.0-CE } \\
\text { relationships. } \\
\text { Need to research on } \\
\text { CE practices and their } \\
\text { sustainability impacts. }\end{array}$ \\
\hline [9] & Massaro et al. & $\begin{array}{l}\text { Need for better } \\
\text { understanding the } \\
\text { union between I4.0 } \\
\text { and CE. }\end{array}$ & $\begin{array}{l}\text { Investigation of the } \\
\text { link between I } 4.0 \text { and } \\
\text { CE, understanding } \\
\text { how I } 4.0 \text { can foster the } \\
\text { impact of CE. } \\
\text { Thematic and content } \\
\text { analysis on grey and } \\
\text { scientific literature, } \\
\text { to get the perspective } \\
\text { of both academia } \\
\text { and practitioners. }\end{array}$ & $\begin{array}{l}\text { The current discussion } \\
\text { concerns mainly the use of } \\
\text { smart services in waste } \\
\text { management, resource } \\
\text { efficiency and } \\
\text { collaboration. } \\
\text { There is the need for a } \\
\text { better operationalization, } \\
\text { also through the } \\
\text { conduction of case studies } \\
\text { rather than } \\
\text { quantitative analysis. }\end{array}$ & $\begin{array}{l}\text { The combination of } \\
\text { grey and scientific } \\
\text { literature limited the } \\
\text { in-depth analysis. } \\
\text { More insights from } \\
\text { business cases } \\
\text { are needed. } \\
\text { No focus on specific } \\
\text { DTs- CE relationships. }\end{array}$ & $\begin{array}{l}\text { Future research } \\
\text { deriving from the } \\
\text { limitations discussed. } \\
\text { Need to address and } \\
\text { bridge the academic } \\
\text { and practitioners' } \\
\text { perspectives } \\
\text { ('third mission' of } \\
\text { universities is } \\
\text { encouraged). }\end{array}$ \\
\hline [59] & Okorie et al. & $\begin{array}{l}\text { The CE transition } \\
\text { requires firms } \\
\text { to evaluate } \\
\text { resource flows, } \\
\text { supply chains, } \\
\text { business models. } \\
\text { The evaluation is } \\
\text { critical for } \\
\text { high-value } \\
\text { manufacturing } \\
\text { (HVM). }\end{array}$ & $\begin{array}{l}\text { Investigation of the } \\
\text { role of value, cost, } \\
\text { and other factors of } \\
\text { influence, as DTs, } \\
\text { in the selection of a } \\
\text { CBM for HVM. }\end{array}$ & $\begin{array}{l}\text { DTs are critical enablers } \\
\text { for CBMs, helping value } \\
\text { creation and capture. } \\
\text { The value reached range } \\
\text { over sustainability areas } \\
\text { and nonconventional } \\
\text { forms of value as } \\
\text { educational/research } \\
\text { value, organizational } \\
\text { value, customer value, } \\
\text { and information value. }\end{array}$ & $\begin{array}{c}\text { Focus on a } \\
\text { specific context. } \\
\text { No focus on specific } \\
\text { aspects of the DTs and } \\
\text { CE relationship. }\end{array}$ & $\begin{array}{l}\text { Need for further } \\
\text { investigation of the } \\
\text { magnitude of the } \\
\text { value generated, } \\
\text { also through the } \\
\text { identification of } \\
\text { appropriate metrics. }\end{array}$ \\
\hline
\end{tabular}


Table 3. Cont.

\begin{tabular}{|c|c|c|c|c|c|c|}
\hline Ref. & Authors & $\begin{array}{l}\text { Context and } \\
\text { Motivation }\end{array}$ & Main Contribution & Main Findings & Main Limitations & $\begin{array}{l}\text { Main Future } \\
\text { Research }\end{array}$ \\
\hline [60] & Ranta et al. & $\begin{array}{l}\text { DTs enable CBMs, } \\
\text { but there is a lack of } \\
\text { understanding of } \\
\text { how the process } \\
\text { takes place. }\end{array}$ & $\begin{array}{l}\text { Conduction of } \\
\text { multiple case studies } \\
\text { in four Northern } \\
\text { Europe-based } \\
\text { forerunner firms with } \\
\text { CBMs enabled by DTs. }\end{array}$ & $\begin{array}{l}\text { Provision of empirical } \\
\text { evidence of improved } \\
\text { resource flows and of } \\
\text { value creation and capture } \\
\text { in firms across } \\
\text { diverse industries. } \\
\text { CMB's innovation is } \\
\text { necessary for radical } \\
\text { improvement toward CE. } \\
\text { The improvements are } \\
\text { enabled more by data } \\
\text { integration and analysis } \\
\text { than by data collection. }\end{array}$ & $\begin{array}{l}\text { Generalizability of the } \\
\text { study limited by } \\
\text { sample selection, } \\
\text { as for awareness } \\
\text { and competences } \\
\text { and specific } \\
\text { contextual factors. } \\
\text { No investigation of } \\
\text { specific DTs. }\end{array}$ & $\begin{array}{l}\text { Need for more } \\
\text { empirical research to } \\
\text { test the findings of } \\
\text { the qualitative } \\
\text { case studies. } \\
\text { Further research } \\
\text { should consider the } \\
\text { B2C sector, } \\
\text { particularly in the } \\
\text { context of } \\
\text { sharing economy. }\end{array}$ \\
\hline [61] & $\begin{array}{l}\text { Rehman } \\
\text { Khan et al. }\end{array}$ & $\begin{array}{l}\text { Blockchain } \\
\text { technology } \\
\text { promises potential } \\
\text { improvements for } \\
\text { the adoption of CE } \\
\text { in SCM. }\end{array}$ & $\begin{array}{l}\text { Investigation of } \\
\text { blockchain } \\
\text { technology's role for } \\
\text { CE to enhance } \\
\text { organizational } \\
\text { performance in the } \\
\text { context of } \\
\text { China-Pakistan- } \\
\text { Economic-Corridor } \\
\text { (CPEC). } \\
\text { Survey of } \\
\text { manufacturing firms. }\end{array}$ & $\begin{array}{l}\text { Blockchain technology is } \\
\text { pivotal in the CE } \\
\text { transition and linked to } \\
\text { visibility, transparency, } \\
\text { smart contracting; these } \\
\text { features are required by } \\
\text { contexts involving several } \\
\text { stakeholders as supply } \\
\text { chains and the CPEC. } \\
\text { Benefits from the adoption } \\
\text { of blockchain address the } \\
\text { overall sustainability in } \\
\text { the long term. }\end{array}$ & $\begin{array}{l}\text { Generalizability of the } \\
\text { study limited by } \\
\text { sample selection. } \\
\text { Focus only on } \\
\text { blockchain technology. }\end{array}$ & n.a. \\
\hline [54] & Upadhyay et al. & $\begin{array}{l}\text { Blockchain research } \\
\text { is developing } \\
\text { rapidly, urging the } \\
\text { investigation over } \\
\text { its implications in } \\
\text { terms of CE and } \\
\text { sustainability. }\end{array}$ & $\begin{array}{l}\text { Critical narrative } \\
\text { review of the } \\
\text { blockchain } \\
\text { technology's } \\
\text { contribution to CE } \\
\text { through the lens of } \\
\text { sustainability and } \\
\text { social responsibility. }\end{array}$ & $\begin{array}{l}\text { Potential alignment of } \\
\text { blockchain with CE } \\
\text { (through reduction of } \\
\text { transaction costs, } \\
\text { enhancement of supply } \\
\text { chain performance and } \\
\text { communication, etc.). } \\
\text { Possible challenges to } \\
\text { blockchain adoption in } \\
\text { terms of trust, illegal } \\
\text { activities, upfront costs. }\end{array}$ & $\begin{array}{c}\text { Narrative review } \\
\text { approach. } \\
\text { Focus only on } \\
\text { blockchain technology. }\end{array}$ & $\begin{array}{l}\text { Future reviews } \\
\text { should entail a } \\
\text { systematic approach. } \\
\text { Need to focus on CE's } \\
\text { social impacts and the } \\
\text { role of contextual } \\
\text { factors on the } \\
\text { adoption of } \\
\text { blockchain } \\
\text { technologies. }\end{array}$ \\
\hline [62] & Bag et al. & $\begin{array}{l}\text { Relevant impact of } \\
\text { DTs on the } \\
\text { procurement } \\
\text { process. }\end{array}$ & $\begin{array}{l}\text { Investigation over the } \\
\text { relationships between } \\
\text { Procurement } 4.0 \text { and } \\
\text { DTs, within the } \\
\text { CE context. } \\
\text { Survey of South } \\
\text { African manufacturers. }\end{array}$ & $\begin{array}{l}\text { Identification of benefits } \\
\text { from I4.0 applications in } \\
\text { the procurement function } \\
\text { within CE. } \\
\text { Firms with a strong } \\
\text { procurement strategy and } \\
\text { effective Procurement } 4.0 \\
\text { processes optimized better } \\
\text { their procurement } \\
\text { processes and attain } \\
\text { enhanced CE } \\
\text { performance. }\end{array}$ & $\begin{array}{l}\text { Generalizability of the } \\
\text { study limited by } \\
\text { sample selection. } \\
\text { Focus only on the } \\
\text { procurement process. } \\
\text { No investigation of } \\
\text { specific DTs. }\end{array}$ & $\begin{array}{l}\text { Need for further } \\
\text { research to test all } \\
\text { the hypothesis. } \\
\text { Need for further } \\
\text { research on possible } \\
\text { moderators of } \\
\text { the effects. }\end{array}$ \\
\hline [63] & Bag et al. & $\begin{array}{l}\text { The overall trend } \\
\text { toward a smart } \\
\text { logistics system } \\
\text { should be better } \\
\text { investigated, } \\
\text { defining how } \\
\text { I4.0 influences } \\
\text { smart logistics. }\end{array}$ & $\begin{array}{l}\text { Survey of South } \\
\text { African executives in } \\
\text { firms operating in } \\
\text { mines, quarries, } \\
\text { and processing plants. }\end{array}$ & $\begin{array}{l}\text { I4.0 supports the } \\
\text { optimization of operations } \\
\text { in the logistics chains. } \\
\text { I4.0 helps to build } \\
\text { dynamic capabilities to } \\
\text { face logistics' uncertainty } \\
\text { and impacts more on } \\
\text { intelligent logistics than } \\
\text { on interconnected and } \\
\text { instrumented logistics. }\end{array}$ & $\begin{array}{l}\text { Generalizability of the } \\
\text { study limited by } \\
\text { sample selection. } \\
\text { Focus only on logistics. } \\
\text { No investigation of } \\
\text { specific DTs. }\end{array}$ & $\begin{array}{l}\text { Need for enlarging } \\
\text { the sample. } \\
\text { Future research could } \\
\text { compare the results } \\
\text { deriving from } \\
\text { different contexts. }\end{array}$ \\
\hline [64] & $\begin{array}{c}\text { Bag \& } \\
\text { Pretorius }\end{array}$ & $\begin{array}{l}\text { DTs entails } \\
\text { challenges and } \\
\text { opportunities for } \\
\text { manufacturing } \\
\text { firms in terms of } \\
\text { sustainability } \\
\text { and CE. }\end{array}$ & $\begin{array}{c}\text { Systematic literature } \\
\text { review on I4.0, } \\
\text { sustainability and CE. } \\
\text { Identification of } \\
\text { barriers and drivers. } \\
\text { Proposal of a research } \\
\text { framework integrating } \\
\text { I4.0, sustainable } \\
\text { manufacturing and CE. }\end{array}$ & $\begin{array}{c}\text { I4.0 can positively } \\
\text { influence sustainable } \\
\text { manufacturing and } \\
\text { CE capabilities. } \\
\text { Industrial } \\
\text { decision-makers should } \\
\text { focus more on sustainable } \\
\text { manufacturing as an } \\
\text { enabler of CE capabilities. }\end{array}$ & $\begin{array}{l}\text { Systematic protocol } \\
\text { limitations as a single } \\
\text { academic source and } \\
\text { timespan considered. } \\
\text { Focus only on BDA. }\end{array}$ & $\begin{array}{l}\text { Future research } \\
\text { should involve a } \\
\text { statistical validation } \\
\text { of the proposed } \\
\text { research framework. }\end{array}$ \\
\hline
\end{tabular}


Table 3. Cont

\begin{tabular}{|c|c|c|c|c|c|c|}
\hline Ref. & Authors & $\begin{array}{l}\text { Context and } \\
\text { Motivation }\end{array}$ & Main Contribution & Main Findings & Main Limitations & $\begin{array}{l}\text { Main Future } \\
\text { Research }\end{array}$ \\
\hline [4] & Cioffi et al. & $\begin{array}{l}\text { Digital innovations } \\
\text { support the CE } \\
\text { transition, } \\
\text { promoting } \\
\text { solutions as } \\
\text { digital platforms, } \\
\text { smart devices, AI. }\end{array}$ & $\begin{array}{l}\text { Systematic literature } \\
\text { review on what } \\
\text { enabling technologies } \\
\text { can promote CBMs. }\end{array}$ & $\begin{array}{l}\text { Innovative technologies } \\
\text { enable CE, but a conscious } \\
\text { innovation path is needed; } \\
\text { despite the benefits, } \\
\text { investments return times } \\
\text { are long. CE adoption } \\
\text { needs managerial and } \\
\text { legislative changes and } \\
\text { can be eased by } \\
\text { digital innovations. }\end{array}$ & $\begin{array}{l}\text { Systematic protocol } \\
\text { limitations. } \\
\text { Keywords used not } \\
\text { totally aligned with aim } \\
\text { of the present research. } \\
\text { Focus on Smart } \\
\text { Manufacturing and } \\
\text { Applied Industrial } \\
\text { Technologies. }\end{array}$ & $\begin{array}{l}\text { Future research } \\
\text { should consider the } \\
\text { evolution of the } \\
\text { academic interest on } \\
\text { the topic. }\end{array}$ \\
\hline [65] & $\begin{array}{l}\text { Cwiklicki \& } \\
\text { Wojnarowska }\end{array}$ & $\begin{array}{l}\text { I4.0 and CE are } \\
\text { pivotal topics in the } \\
\text { current debate but } \\
\text { need to be } \\
\text { better linked. }\end{array}$ & $\begin{array}{l}\text { Identification of the } \\
\text { relationships between } \\
\text { the CE and I4.0. }\end{array}$ & $\begin{array}{l}\text { CE can be implemented } \\
\text { using I4.0: industrial } \\
\text { decision-makers can focus } \\
\text { on specific CE goals and } \\
\text { identify the DTs best } \\
\text { supporting them. } \\
\text { I4.0's main contribution } \\
\text { toward CE relates to } \\
\text { recycle/reuse strategies. } \\
\text { The most impacting DTs } \\
\text { are IoT and BDA. }\end{array}$ & $\begin{array}{l}\text { Limitations resulting } \\
\text { from the blurred } \\
\text { concepts of I4.0 } \\
\text { and CE. } \\
\text { No investigation of } \\
\text { specific DTs nor specific } \\
\text { CE aspects. }\end{array}$ & $\begin{array}{l}\text { Future research } \\
\text { should move from the } \\
\text { micro-level to the } \\
\text { supply chain level. }\end{array}$ \\
\hline [66] & $\begin{array}{l}\text { De Marchi \& } \\
\text { Di Maria }\end{array}$ & $\begin{array}{l}\text { Promising positive } \\
\text { scenarios for } \\
\text { circular-oriented } \\
\text { firms to control the } \\
\text { use of resources } \\
\text { and monitor } \\
\text { internal and } \\
\text { external processes } \\
\text { from DTs' adoption. }\end{array}$ & $\begin{array}{l}\text { Empirical investigation } \\
\text { of the connections } \\
\text { between I4.0 and } \\
\text { CE strategies. } \\
\text { Survey of North Italy } \\
\text { manufacturing firms. }\end{array}$ & $\begin{array}{l}\text { Positive relationship } \\
\text { between I4.0 and CE } \\
\text { adopters, with DTs acting } \\
\text { as both enablers and } \\
\text { amplifiers of CE. } \\
\text { Differences emerge in } \\
\text { terms of specific } \\
\text { technologies adopted and } \\
\text { their implications on the } \\
\text { value chain's activities }\end{array}$ & $\begin{array}{l}\text { Generalizability of the } \\
\text { study limited by } \\
\text { sample selection. } \\
\text { No investigation of } \\
\text { specific DTs; focus on } \\
\text { limited CE aspects. }\end{array}$ & $\begin{array}{l}\text { Further research } \\
\text { should investigate the } \\
\text { topic more } \\
\text { extensively, } \\
\text { understanding the } \\
\text { specific role played by } \\
\text { each DT. }\end{array}$ \\
\hline [67] & $\begin{array}{l}\text { Demestichas } \\
\text { \& Daskalakis }\end{array}$ & $\begin{array}{l}\text { CE and Information } \\
\text { and communication } \\
\text { technology (ICT) } \\
\text { are pivotal topics in } \\
\text { the current debate. } \\
\text { These technologies } \\
\text { can enable CE. }\end{array}$ & $\begin{array}{l}\text { Extensive academic } \\
\text { literature review on } \\
\text { prominent ICT } \\
\text { solutions paving the } \\
\text { way to CE. }\end{array}$ & $\begin{array}{l}\text { The most popular ICT are } \\
\text { those allowing data } \\
\text { collection analysis, } \\
\text { like IoT, blockchain, AI. } \\
\text { As for CE, the focus is } \\
\text { mainly on the } \\
\text { reduce component. } \\
\text { Barriers to the adoption of } \\
\text { ICT for CE are related to } \\
\text { consumer, costs, lack of } \\
\text { education on CE and } \\
\text { familiarization } \\
\text { with technologies. }\end{array}$ & $\begin{array}{l}\text { Systematic protocol } \\
\text { limitations. } \\
\text { No investigation of } \\
\text { specific DTs nor specific } \\
\text { CE aspects. }\end{array}$ & $\begin{array}{l}\text { Need for efforts to } \\
\text { increase CE } \\
\text { awareness among } \\
\text { industrial } \\
\text { decision-makers. } \\
\text { Need for metrics to } \\
\text { prioritize CE efforts. }\end{array}$ \\
\hline
\end{tabular}

Firms are looking for a high level

[68] Dev et al. of operational excellence through the developments of I4.0 technologies.

\section{Proposal for a roadmap for} sustainable reverse supply chain/logistics operations excellence by jointly implementing I4.0 and CE. Focus on an RFID-enabled system and reverse logistics simulation.
Insights for full circularity adoption for sustainable operations management viá inventory and production planning,

AM set-up, family-based dispatching rules, and transportation system of the reverse logistics.
Future research

The results obtained are context specific. Focus on limited DTs and limited CE aspects. generalizability of results.

Future research could deal with multiple suppliers.

I4.0 creates opportunities for supply chain

$$
\text { networks; }
$$

[69] Esmaeilian et al. more details are needed on how I4.0 addresses sustainability and

CE challenges.

Design for disassembly is pivotal for the development of new business models based on the I4.0 and CE paradigms.
Review on blockchain technology and I4.0 for advancing supply chains towards sustainability.

Proposal of a method to sort and cluster big data related to disassembly time and operations from different industrial sources. Preliminary evaluation through a case study.
Identification of I4.0 capabilities for sustainability and of their main impacts on CE.
Systematic protocol limitations. Focus only on

blockchain technology and IoT.
Need for empirical research, particularly on the blockchain. Future research should consider the complexity of

multi-tiers supply chains and the needs of multiple stakeholders.

\section{Future research} should provide more empirical applications. systematic procedure entailing the most relevant statistical algorithms based on data collected according to I4.0 paradigm, to deepen the knowledge on disassembly.
Limited empirical test of the proposed method.

Focus only on disassembly.
Future research

digitalization of the data collection process 
Table 3. Cont

\begin{tabular}{|c|c|c|c|c|c|c|}
\hline Ref. & Authors & $\begin{array}{l}\text { Context and } \\
\text { Motivation }\end{array}$ & Main Contribution & Main Findings & Main Limitations & $\begin{array}{l}\text { Main Future } \\
\text { Research }\end{array}$ \\
\hline [71] & Getor et al. & $\begin{array}{l}\text { Urge to shift from } \\
\text { the linear model of } \\
\text { tackling the plastic } \\
\text { waste issue to a } \\
\text { CE one. }\end{array}$ & $\begin{array}{l}\text { Proposal for a } \\
\text { framework integrating } \\
\text { AI/database interface } \\
\text { for the analysis of } \\
\text { historical and real-time } \\
\text { data, allowing } \\
\text { simultaneous quality } \\
\text { control checks and } \\
\text { thermal stability tests } \\
\text { on different } \\
\text { virgin-recycled resin } \\
\text { mixing ratios. }\end{array}$ & $\begin{array}{l}\text { The information on the } \\
\text { thermal and mechanical } \\
\text { properties and structure of } \\
\text { resin available through } \\
\text { the system will be a } \\
\text { reference point for } \\
\text { production engineers. } \\
\text { AI allows production } \\
\text { engineers to carry out } \\
\text { analysis on the data } \\
\text { captured by the system. }\end{array}$ & $\begin{array}{l}\text { No practical } \\
\text { application. } \\
\text { The real-life } \\
\text { application could face } \\
\text { challenges and } \\
\text { require several } \\
\text { trial-and-error rounds. } \\
\text { Focus only on limited } \\
\text { DTs and on a very } \\
\text { specific context. }\end{array}$ & $\begin{array}{l}\text { Further research } \\
\text { should focus on the } \\
\text { conduction of } \\
\text { case studies. }\end{array}$ \\
\hline [72] & $\begin{array}{l}\text { Ghoreishi \& } \\
\text { Happonen }\end{array}$ & $\begin{array}{l}\text { Designing products } \\
\text { for circularity is } \\
\text { rising in relevance. } \\
\text { Parallelly, } \\
\text { the adoption of AI } \\
\text { in CE solutions } \\
\text { increases } \\
\text { productivity. }\end{array}$ & $\begin{array}{c}\text { Investigation on how } \\
\text { AI can integrate with } \\
\text { CE as for the product } \\
\text { design phase. }\end{array}$ & $\begin{array}{l}\text { AI helps the optimization } \\
\text { of resources for product } \\
\text { design, the collection of } \\
\text { data on products' lifecycle, } \\
\text { the remote monitoring, } \\
\text { reuse and } \\
\text { remanufacturing } \\
\text { of products. }\end{array}$ & $\begin{array}{l}\text { Generalizability of the } \\
\text { study limited by } \\
\text { sample selection. } \\
\text { Focus on limited DTs. }\end{array}$ & $\begin{array}{l}\text { Future research } \\
\text { should focus on the } \\
\text { identification of } \\
\text { barriers and drivers to } \\
\text { the adoption of AI for } \\
\text { CE, addressing also } \\
\text { AI and CE integration } \\
\text { in industrial systems } \\
\text { as supply chains. }\end{array}$ \\
\hline [15] & $\begin{array}{l}\text { Ghoreishi \& } \\
\text { Happonen }\end{array}$ & $\begin{array}{c}\text { I4.0 helps to } \\
\text { overcome the } \\
\text { challenges towards } \\
\text { CE transition. } \\
\text { The application of } \\
\text { CE strategies at a } \\
\text { product planning } \\
\text { stage brings } \\
\text { environmental } \\
\text { benefits. }\end{array}$ & $\begin{array}{l}\text { Review of the role of } \\
\text { AI as an accelerator } \\
\text { in circular } \\
\text { product design. }\end{array}$ & $\begin{array}{l}\text { AI enhancements in } \\
\text { business models that } \\
\text { support CE are pivotal for } \\
\text { the growth and } \\
\text { competitiveness of } \\
\text { the industries. }\end{array}$ & Review limitations. & $\begin{array}{l}\text { Need for better detail } \\
\text { the AI's impact on } \\
\text { different CE aspects, } \\
\text { while also } \\
\text { understanding the } \\
\text { barriers to the } \\
\text { adoption of I4.0 and } \\
\text { the benefits deriving } \\
\text { from it. }\end{array}$ \\
\hline
\end{tabular}

The enabling capabilities of IoT over CE are

[73] Ingemarsdotter recognized, but it is not clear how to leverage on IoT in the implementations of CE strategies.
Investigation over the mismatch between the 'theoretical opportunities' of IoT

for $\mathrm{CE}$ and the actual implementation in practice.

Case study within a LED company, with previous experience and knowledge on IoT and $\mathrm{CE}$.

Proposal for an

I4.0 can help in meeting a more efficient recycling process.

[74] Kintscher et al.
IoT supports: servitized business models; tracking of products; conditions monitoring and predictive maintenance; estimations of remaining lifetime; design decisions to improve durability. Implementation

challenges lay in the lack of structured data

management processe and the difficulty of designing IoT-enabled products.

The information share in supply chains is pivotal for enabling an efficient recycling process. Information can be collected and shared on a marketplace.

Blockchain allows

transparent, decentralized, secure transaction processes and, positively impacts on the overall sustainability.

Blockchain adoption echnology and are emergent concepts;

[75] Kouhizade the breadth of the blockchain concept and its applications require investigation.

Grounded theory building based on multiple case studies, linking the blockchain applications to the ReSOLVE framework.

suffers from infrastructure challenges. Variations across industries and firms' size in blockchain technology adoption for various CE practices are observed.
Exploration of how AM can CE strategies.

Identification of the key sustainability aspects to consider in the design of AM-enabled CE strategies.

\section{AM supports several CE} strategies and CBMs.

Sustainability aspects must be considered at a planning and design stage and used to point out improvement opportunities.
Generalizability of the study limited by sample selection. Focus on limited IoTs.

Generalizability of the study limited by sample selection.

Focus on the recycling process.
Future research should consider the conduction of additional case studies. Future research should focus on data management in the context of IoT for CE.

Need to enlarge the sample.
Generalizability of the study limited by sample selection. Focus only on blockchain technology.
Need for more empirical evidence, particularly on the long-term impacts of the blockchain technology on $\mathrm{CE}$. Future research should also focus on the adoption of blockchain in supply chains.
Sustainability aspects are identified but not linked to any specific

$$
\text { CE strategy. }
$$

Focus only on AM.
Need for a case-by-case analysis for the identification of tailored

AM-enabled technology sustainability wise. 
Table 3. Cont.

\begin{tabular}{|c|c|c|c|c|c|c|}
\hline Ref. & Authors & $\begin{array}{l}\text { Context and } \\
\text { Motivation }\end{array}$ & Main Contribution & Main Findings & Main Limitations & $\begin{array}{c}\text { Main Future } \\
\text { Research }\end{array}$ \\
\hline [77] & $\begin{array}{l}\text { Kristoffersen } \\
\text { et al. }\end{array}$ & $\begin{array}{l}\text { More guidance is } \\
\text { needed on how DTs } \\
\text { (as IoT and BDA) } \\
\text { can enable CE for } \\
\text { improved efficiency } \\
\text { and productivity. }\end{array}$ & $\begin{array}{c}\text { Proposal of a } \\
\text { theoretically grounded } \\
\text { framework and a } \\
\text { database of examples } \\
\text { of the Smart CE to } \\
\text { achieve SDG } 12 .\end{array}$ & $\begin{array}{l}\text { DTs hold several } \\
\text { potentials for improved } \\
\text { efficiency and } \\
\text { productivity. } \\
\text { The framework can } \\
\text { represent an assessment } \\
\text { tool to evaluate the DTs } \\
\text { capabilities in firms. }\end{array}$ & $\begin{array}{l}\text { First step in detailing } \\
\text { mechanisms and } \\
\text { strategies of a Smart } \\
\text { CE, limited to } \\
\text { theoretical grounding. } \\
\text { Focus only on IoT } \\
\text { and BDA. }\end{array}$ & $\begin{array}{c}\text { Future research } \\
\text { should provide } \\
\text { empirical evidence on } \\
\text { the Smart CE, } \\
\text { also validating the } \\
\text { proposed framework. }\end{array}$ \\
\hline$[78]$ & Mboli et al. & $\begin{array}{l}\text { As firms are } \\
\text { transitioning to CE, } \\
\text { technologies } \\
\text { allowing the } \\
\text { predicting, tracking } \\
\text { and monitoring of } \\
\text { product's residual } \\
\text { value must } \\
\text { be identified. }\end{array}$ & $\begin{array}{c}\text { Proposal for an } \\
\text { IoT-enabled decision } \\
\text { support system } \\
\text { for CBMs. } \\
\text { Experimental study } \\
\text { with a real-world case } \\
\text { in the electronic } \\
\text { consumer sector. }\end{array}$ & $\begin{array}{c}\text { Products can be tracked } \\
\text { and monitored in } \\
\text { real-time, through IoT, } \\
\text { allowing } \\
\text { business analytics. } \\
\text { The adoption on the } \\
\text { proposed system may } \\
\text { support firms in creating } \\
\text { more value compared to a } \\
\text { linear economy. }\end{array}$ & $\begin{array}{l}\text { Generalizability of the } \\
\text { study limited by } \\
\text { sample selection. } \\
\text { Focus only on IoT. }\end{array}$ & $\begin{array}{l}\text { Future research is } \\
\text { aimed at focusing on } \\
\text { the logistics } \\
\text { optimization and } \\
\text { price and } \\
\text { cost prediction. }\end{array}$ \\
\hline [79] & Moller & $\begin{array}{c}\text { CE is important } \\
\text { within I4.0, and a } \\
\text { future ecological } \\
\text { and economical } \\
\text { model. }\end{array}$ & $\begin{array}{l}\text { Analysis of the digital } \\
\text { transformation as an } \\
\text { enabler of intelligent } \\
\text { manufacturing and its } \\
\text { opportunities to CE. }\end{array}$ & $\begin{array}{l}\text { Discussion over the needs } \\
\text { for the development of an } \\
\text { integrated approach and } \\
\text { description of the } \\
\text { background for the } \\
\text { development. }\end{array}$ & $\begin{array}{l}\text { No investigation of } \\
\text { specific DTs nor specific } \\
\text { CE aspects. }\end{array}$ & $\begin{array}{l}\text { Need for more inter- } \\
\text { and transdisciplinary } \\
\text { research to achieve an } \\
\text { intelligent CE. }\end{array}$ \\
\hline $\begin{array}{l}{[80,} \\
81]\end{array}$ & $\begin{array}{l}\text { Nobre \& } \\
\text { Tavares }\end{array}$ & $\begin{array}{l}\text { Information } \\
\text { technology (IT) } \\
\text { professionals } \\
\text { should incorporate } \\
\text { projects focusing on } \\
\text { the organizations' } \\
\text { CE transition. }\end{array}$ & $\begin{array}{l}\text { Development of a } \\
\text { framework for the } \\
\text { identification of the IT } \\
\text { capabilities necessary } \\
\text { for organizations to } \\
\text { be considered } \\
\text { technologically circular. }\end{array}$ & $\begin{array}{l}\text { Extension of the existing } \\
\text { ReSOLVE framework to } \\
\text { allow IT professionals to } \\
\text { assess their current CE } \\
\text { gaps, with the aim of fill } \\
\text { these gaps and foster the } \\
\text { CE transition. } \\
\text { Identification of I4.0's role } \\
\text { in the CE transition. }\end{array}$ & $\begin{array}{c}\text { The proposed } \\
\text { framework could } \\
\text { become obsolete due } \\
\text { to the rapid evolution } \\
\text { of technologies, and it } \\
\text { lacks practical } \\
\text { confirmation through } \\
\text { case studies. } \\
\text { Focus only on IoT } \\
\text { and BDA. }\end{array}$ & $\begin{array}{l}\text { Need for an empirical } \\
\text { validation of } \\
\text { the framework. } \\
\text { Future research } \\
\text { should focus on the } \\
\text { development of } \\
\text { metrics to self-assess } \\
\text { and benchmark } \\
\text { the capabilities. }\end{array}$ \\
\hline [82] & Piscitelli et al. & $\begin{array}{l}\text { The full adoption of } \\
\text { CE principles } \\
\text { within } \\
\text { organizations and } \\
\text { supply chains } \\
\text { encounters } \\
\text { obstacles related to } \\
\text { the lack of } \\
\text { advanced } \\
\text { technologies. }\end{array}$ & $\begin{array}{c}\text { Systematic review of } \\
\text { literature related to CE } \\
\text { from an I4.0 } \\
\text { perspective, } \\
\text { understanding how } \\
\text { I4.0 technologies can } \\
\text { unlock the circularity } \\
\text { of resources. }\end{array}$ & $\begin{array}{l}\text { CE and I4.0 are closely } \\
\text { linked. Technologies } \\
\text { support CE in the ability } \\
\text { to have more knowledge } \\
\text { and in the monitoring of } \\
\text { processes and products. } \\
\text { CE shows great } \\
\text { applications potential in } \\
\text { many contexts. }\end{array}$ & $\begin{array}{l}\text { Systematic protocol } \\
\text { limitations. } \\
\text { No investigation of } \\
\text { specific DTs. }\end{array}$ & n.a. \\
\hline [83] & $\begin{array}{l}\text { Poschmann } \\
\text { et al. }\end{array}$ & $\begin{array}{l}\text { Robotics can } \\
\text { support the } \\
\text { disassembly } \\
\text { process, which is } \\
\text { essential for } \\
\text { implementing CE. }\end{array}$ & $\begin{array}{l}\text { Systematic literature } \\
\text { review on robotics } \\
\text { in disassembly. }\end{array}$ & $\begin{array}{l}\text { Predefined processes and } \\
\text { flexible automation are } \\
\text { main research streams. } \\
\text { Ample possibilities for } \\
\text { integrating the } \\
\text { disassembly processes } \\
\text { into a superordinate CE } \\
\text { information system. }\end{array}$ & $\begin{array}{c}\text { Systematic protocol } \\
\text { limitations } \\
\text { (search string). } \\
\text { Focus only on } \\
\text { disassembly and ROB. }\end{array}$ & $\begin{array}{l}\text { Future research will } \\
\text { focus on the } \\
\text { information processes } \\
\text { and system concepts } \\
\text { towards an } \\
\text { autonomous } \\
\text { disassembly system. }\end{array}$ \\
\hline [84] & $\begin{array}{l}\text { Rajput \& } \\
\text { Singh }\end{array}$ & $\begin{array}{c}\text { The adoption of I4.0 } \\
\text { can impact } \\
\text { positively on CE } \\
\text { and cleaner } \\
\text { production. }\end{array}$ & $\begin{array}{l}\text { Proposal for a model } \\
\text { for I4.0 set-up to } \\
\text { achieve CE and cleaner } \\
\text { production, through } \\
\text { the optimization of } \\
\text { products-machine } \\
\text { allocation. }\end{array}$ & $\begin{array}{l}\text { The proposed model } \\
\text { optimizes trade-offs } \\
\text { between energy } \\
\text { consumption and machine } \\
\text { processing cost, achieving } \\
\text { CE and cleaner } \\
\text { production. }\end{array}$ & $\begin{array}{l}\text { The model is } \\
\text { developed according } \\
\text { to specific hypotheses. } \\
\text { No investigation of } \\
\text { specific DTs nor specific } \\
\text { CE aspects. }\end{array}$ & $\begin{array}{c}\text { Future research } \\
\text { deriving from the } \\
\text { limitations discussed. }\end{array}$ \\
\hline [85] & Rocca et al. & $\begin{array}{l}\text { Companies are } \\
\text { urged to re-think } \\
\text { their business } \\
\text { strategies in view of } \\
\text { both the CE and } \\
\text { I4.0 paradigms. }\end{array}$ & $\begin{array}{l}\text { Presentation of a } \\
\text { laboratory application } \\
\text { case, testing an } \\
\text { electrical and } \\
\text { electronic equipment } \\
\text { disassembly plant } \\
\text { configuration through } \\
\text { a set of } \\
\text { simulation tools. }\end{array}$ & $\begin{array}{l}\text { Practical demonstration } \\
\text { through a laboratory } \\
\text { experiment of DTs } \\
\text { enabling CE. } \\
\text { DTs allow better use of } \\
\text { resources, increased } \\
\text { production sustainability } \\
\text { and benefits along the } \\
\text { product lifecycle. }\end{array}$ & $\begin{array}{l}\text { Generalizability of the } \\
\text { study limited by the } \\
\text { specific context } \\
\text { investigated. } \\
\text { Focus only on } \\
\text { disassembly and ROB, } \\
\text { SIM, AM. }\end{array}$ & n.a. \\
\hline [31] & Rosa et al. & $\begin{array}{l}\text { I4.0 and CE are } \\
\text { pivotal current } \\
\text { topics. They can be } \\
\text { described as } \\
\text { independent, } \\
\text { but overlaps } \\
\text { are identified. }\end{array}$ & $\begin{array}{l}\text { Systematic literature } \\
\text { review on the relations } \\
\text { between I4.0 and CE. } \\
\text { A useful double } \\
\text { perspective is offered. }\end{array}$ & $\begin{array}{l}\text { I4.0 can generally } \\
\text { positively impact the } \\
\text { lifecycle management of } \\
\text { products and specific } \\
\text { insights are dependent on } \\
\text { the DTs considered. }\end{array}$ & $\begin{array}{c}\text { Systematic protocol } \\
\text { limitations. } \\
\text { No focus on } \\
\text { operationalization. }\end{array}$ & $\begin{array}{l}\text { Need for empirical } \\
\text { evidence on how CE } \\
\text { and I4.0 are applied } \\
\text { in practice. }\end{array}$ \\
\hline
\end{tabular}


Table 3. Cont.

\begin{tabular}{|c|c|c|c|c|c|c|}
\hline Ref. & Authors & $\begin{array}{l}\text { Context and } \\
\text { Motivation }\end{array}$ & Main Contribution & Main Findings & Main Limitations & $\begin{array}{c}\text { Main Future } \\
\text { Research }\end{array}$ \\
\hline [86] & Rossi et al. & $\begin{array}{l}\text { CE is recognized as } \\
\text { a source of value } \\
\text { creation, but its } \\
\text { application is still } \\
\text { lagging. I4.0 can } \\
\text { support CE } \\
\text { implementation. }\end{array}$ & $\begin{array}{l}\text { Evaluation of how and } \\
\text { how much CBMs are } \\
\text { enhanced by I4.0. } \\
\text { Analysis based on } \\
\text { literature case studies, } \\
\text { and on the application } \\
\text { of an assessment tool } \\
\text { with secondary data. }\end{array}$ & $\begin{array}{l}\text { Proposal of a systematized } \\
\text { framework considering } \\
\text { CBMs enhanced by } \\
\text { intelligent assets, allowing } \\
\text { the gathering of timely } \\
\text { and consistent data for } \\
\text { reliable decision making. }\end{array}$ & $\begin{array}{l}\text { Framework validity } \\
\text { assessed only through } \\
\text { secondary data. }\end{array}$ & $\begin{array}{l}\text { Need for a systematic } \\
\text { literature review } \\
\text { on the topic. } \\
\text { Need for empirical } \\
\text { application of } \\
\text { the framework. }\end{array}$ \\
\hline [87] & Uçar et al. & $\begin{array}{l}\text { DTs as IoT, BDA } \\
\text { and AI are main } \\
\text { supporters for CE, } \\
\text { but DTs specific } \\
\text { effects on CE are } \\
\text { not explored. }\end{array}$ & $\begin{array}{l}\text { Identification of the } \\
\text { roles of DTs } \\
\text { supporting CE through } \\
\text { literature review and } \\
\text { case studies. }\end{array}$ & $\begin{array}{l}\text { DTs can act as enablers or } \\
\text { triggers, with the former } \\
\text { being the dominant ones. }\end{array}$ & $\begin{array}{l}\text { Findings based only } \\
\text { on secondary data. } \\
\text { Focus only on IoT, } \\
\text { BDA and CLOUD. }\end{array}$ & $\begin{array}{l}\text { Need for empirical } \\
\text { research to further } \\
\text { validate the study } \\
\text { findings and consider } \\
\text { different contexts } \\
\text { of application. }\end{array}$ \\
\hline [88] & Yadav et al. & $\begin{array}{l}\text { The discourse on } \\
\text { the adoption of } \\
\text { Sustainable Supply } \\
\text { Chain Management } \\
\text { (SSCM) need to } \\
\text { be updated } \\
\text { accordingly to } \\
\text { changing business } \\
\text { environments. }\end{array}$ & $\begin{array}{c}\text { Development of a } \\
\text { framework to } \\
\text { overcome SSCM } \\
\text { challenges through I4.0 } \\
\text { and CE solutions. } \\
\text { Test of the framework } \\
\text { through hybrid Best } \\
\text { Worst Method in } \\
\text { the Indian } \\
\text { automotive sector. }\end{array}$ & $\begin{array}{c}\text { Identification of } 28 \text { SSCM } \\
\text { challenges and } 22 \text { solution } \\
\text { measures. } \\
\text { Managerial, } \\
\text { organizational and } \\
\text { economic challenges } \\
\text { emerge as the } \\
\text { most critical. }\end{array}$ & $\begin{array}{l}\text { Generalizability of the } \\
\text { study limited by the } \\
\text { specific context } \\
\text { investigated. } \\
\text { Focus only on SCM. }\end{array}$ & $\begin{array}{l}\text { Future research } \\
\text { should consider large } \\
\text { scale application, } \\
\text { as well as the } \\
\text { validation of the } \\
\text { framework in } \\
\text { other contexts. }\end{array}$ \\
\hline [89] & Alcayaga et al. & $\begin{array}{l}\text { The discourse on } \\
\text { circular strategies, } \\
\text { smart products and } \\
\text { product- service } \\
\text { systems has been } \\
\text { addressed in } \\
\text { isolated ways or } \\
\text { with partial } \\
\text { overlaps, a holistic } \\
\text { overview } \\
\text { is missing. }\end{array}$ & $\begin{array}{l}\text { Synthesis of the } \\
\text { literature from the } \\
\text { three domains, } \\
\text { describing } \\
\text { interrelations among } \\
\text { the concepts. } \\
\text { Proposal of a } \\
\text { conceptual framework } \\
\text { of smart-circular } \\
\text { systems, extending the } \\
\text { technical loops. }\end{array}$ & $\begin{array}{l}\text { Better understanding of } \\
\text { smart-circular systems } \\
\text { and outlines of a } \\
\text { research agenda. }\end{array}$ & $\begin{array}{l}\text { Integrative literature } \\
\text { limitations as for the } \\
\text { identification of } \\
\text { relevant literature. } \\
\text { No empirical } \\
\text { validation of } \\
\text { the framework. }\end{array}$ & $\begin{array}{c}\text { Need for } \\
\text { evidence-based } \\
\text { knowledge, through } \\
\text { insights from } \\
\text { empirical studies. } \\
\text { Need for } \\
\text { cross-sectional and } \\
\text { longitudinal studies. } \\
\text { Future research } \\
\text { should investigate } \\
\text { smart-circular } \\
\text { strategies. }\end{array}$ \\
\hline$[90]$ & Cezarino et al. & $\begin{array}{l}\text { I4.0 can potentially } \\
\text { unlock sustainabil- } \\
\text { ity and CE in } \\
\text { emerging } \\
\text { economies, } \\
\text { but further } \\
\text { investigation } \\
\text { is needed. }\end{array}$ & $\begin{array}{l}\text { Investigation of the } \\
\text { relationships between } \\
\text { I4.0 and CE and the } \\
\text { limitations for their } \\
\text { adoption, focusing } \\
\text { on Brazil. } \\
\text { Proposal of a } \\
\text { framework to } \\
\text { overcome limitations. }\end{array}$ & $\begin{array}{l}\text { Exploration of the } \\
\text { relationships between I4.0 } \\
\text { and CE through four } \\
\text { perspectives: political, } \\
\text { economic, social and } \\
\text { technological. }\end{array}$ & $\begin{array}{l}\text { Generalizability of the } \\
\text { study limited by the } \\
\text { specific context } \\
\text { investigated. } \\
\text { No investigation of } \\
\text { specific DTs. }\end{array}$ & $\begin{array}{l}\text { Need for empirical } \\
\text { research to collecting } \\
\text { primary data. } \\
\text { Future research } \\
\text { should address other } \\
\text { emerging economies. }\end{array}$ \\
\hline [55] & $\begin{array}{l}\text { Chiappetta } \\
\text { Jabbour et al. }\end{array}$ & $\begin{array}{l}\mathrm{CE} \text { and big data } \\
\text { present several } \\
\text { synergistic } \\
\text { relationships. }\end{array}$ & $\begin{array}{c}\text { Integration of CE and } \\
\text { big data. } \\
\text { Proposal of a ReSOLVE } \\
\text { based models with the } \\
\text { identification of key } \\
\text { stakeholders and the } \\
\text { management of } \\
\text { volume, velocity, } \\
\text { variety, and veracity of } \\
\text { big data. }\end{array}$ & $\begin{array}{c}\text { Development of an } \\
\text { integrative framework, } \\
\text { enhancing the } \\
\text { comprehension of the } \\
\text { CE-big data nexus. } \\
\text { Development of a matrix } \\
\text { illustrating the complexity } \\
\text { of large-scale data } \\
\text { and stakeholders' } \\
\text { management. } \\
\text { Outline of a } \\
\text { research agenda. }\end{array}$ & $\begin{array}{l}\text { No empirical } \\
\text { validation of the } \\
\text { framework and the } \\
\text { relational matrix. } \\
\text { Focus only on IoT } \\
\text { and BDA. }\end{array}$ & $\begin{array}{l}\text { Need for an empirical } \\
\text { validation of the } \\
\text { framework and the } \\
\text { relational matrix. } \\
\text { Need for empirical } \\
\text { research to test } \\
\text { the suggested } \\
\text { propositions. }\end{array}$ \\
\hline [91] & Charnley et al. & $\begin{array}{l}\text { Growing interest in } \\
\text { the relationships } \\
\text { between CE and } \\
\text { I4.0, but deeper } \\
\text { knowledge } \\
\text { is needed. }\end{array}$ & $\begin{array}{l}\text { Investigation on how } \\
\text { simulation informed } \\
\text { by I4.0 and IoT can } \\
\text { accelerate the adoption } \\
\text { of circular approaches } \\
\text { in UK manufacturing. }\end{array}$ & $\begin{array}{l}\text { The analysis of in-service } \\
\text { data from automotive } \\
\text { components can influence } \\
\text { decisions surrounding } \\
\text { remanufacture and can } \\
\text { lead to significant cost, } \\
\text { material and } \\
\text { resource savings. }\end{array}$ & $\begin{array}{l}\text { Generalizability of the } \\
\text { study limited by the } \\
\text { specific context } \\
\text { investigated. } \\
\text { Focus only on } \\
\text { remanufacturing } \\
\text { and SIM. }\end{array}$ & $\begin{array}{l}\text { Future research } \\
\text { should base on the } \\
\text { study to conduct } \\
\text { more quantitative } \\
\text { and mathematical } \\
\text { evaluations. }\end{array}$ \\
\hline [12] & Chauhan et al. & $\begin{array}{l}\text { I4.0 and CE } \\
\text { attracted the } \\
\text { attention of } \\
\text { academia and } \\
\text { practitioners, } \\
\text { and the connection } \\
\text { between them } \\
\text { need further } \\
\text { investigation. }\end{array}$ & $\begin{array}{l}\text { Application of the } \\
\text { situation, actor, } \\
\text { process, learning, } \\
\text { action, performance } \\
\text { linkages framework to } \\
\text { analyze the role of I4.0 } \\
\text { in realizing CE. }\end{array}$ & $\begin{array}{c}\text { Top managers are } \\
\text { essential actors for } \\
\text { integrating I4.0 to achieve } \\
\text { sustainability, in light } \\
\text { of CE. } \\
\text { IoT and CYB are pivotal } \\
\text { for supporting } \\
\text { CE transition. }\end{array}$ & $\begin{array}{l}\text { Limitations related to } \\
\text { the possible biased of } \\
\text { experts' judgments. }\end{array}$ & $\begin{array}{l}\text { Need for conducting } \\
\text { case studies so to } \\
\text { understand the roles } \\
\text { of digitization and } \\
\text { data-driven } \\
\text { technologies in } \\
\text { achieving the goals } \\
\text { of CE. }\end{array}$ \\
\hline
\end{tabular}


Table 3. Cont

\begin{tabular}{|c|c|c|c|c|c|c|}
\hline Ref. & Authors & $\begin{array}{l}\text { Context and } \\
\text { Motivation }\end{array}$ & Main Contribution & Main Findings & Main Limitations & $\begin{array}{l}\text { Main Future } \\
\text { Research }\end{array}$ \\
\hline [92] & $\begin{array}{l}\text { Garcia-Muiña } \\
\text { et al. }\end{array}$ & $\begin{array}{l}\text { Eco-design, } \\
\text { associated with IoT } \\
\text { technologies can } \\
\text { help in developing } \\
\text { products consistent } \\
\text { with CE principles. }\end{array}$ & $\begin{array}{l}\text { Test of eco-design as a } \\
\text { tool to define an } \\
\text { equilibrium between } \\
\text { sustainability and CE } \\
\text { in the manufacturing } \\
\text { environment of } \\
\text { ceramic tile production. } \\
\text { Identification of IoT as } \\
\text { an enabler for CBMs. }\end{array}$ & $\begin{array}{l}\text { Empirical validation in } \\
\text { a manufacturing } \\
\text { environment of } \\
\text { sustainability paradigms } \\
\text { through eco-design tools } \\
\text { and DTs, proposing the } \\
\text { CBM as an operational } \\
\text { tool to promote the } \\
\text { competitiveness } \\
\text { of enterprises. }\end{array}$ & $\begin{array}{l}\text { Generalizability of the } \\
\text { study limited by the } \\
\text { specific context } \\
\text { investigated. } \\
\text { Focus only on IoT. }\end{array}$ & n.a. \\
\hline [93] & $\begin{array}{l}\text { Garrido- } \\
\text { Hidalgo } \\
\text { et al. }\end{array}$ & $\begin{array}{c}\text { Growing need to } \\
\text { manage backward } \\
\text { materials and } \\
\text { information flows } \\
\text { in the supply chain, } \\
\text { through approaches } \\
\text { based on } \\
\text { Information and } \\
\text { Communication } \\
\text { Technologies (ICT). }\end{array}$ & $\begin{array}{l}\text { Proposal for an } \\
\text { end-to-end solution for } \\
\text { Reverse Supply Chain } \\
\text { Management based } \\
\text { on ICT. } \\
\text { Application to an } \\
\text { industrial case study } \\
\text { regarding WEEE } \\
\text { recovery towards CE. }\end{array}$ & $\begin{array}{l}\text { Demonstration of the } \\
\text { potential of ICT adoption } \\
\text { for Reverse Supply } \\
\text { Chain Management. } \\
\text { IoT facilitates information } \\
\text { management, contributing } \\
\text { to CE transition. } \\
\text { Identification of } \\
\text { communication } \\
\text { bottlenecks that need to be } \\
\text { tackled to enhance the } \\
\text { reliability of large-scale } \\
\text { IoT networks. }\end{array}$ & $\begin{array}{l}\text { Generalizability of the } \\
\text { study limited by the } \\
\text { specific context } \\
\text { investigated. } \\
\text { Focus only on IoT } \\
\text { and CLOUD. }\end{array}$ & $\begin{array}{c}\text { Future research will } \\
\text { assess the economic } \\
\text { and environmental } \\
\text { viability of the } \\
\text { proposed approach. }\end{array}$ \\
\hline [94] & Gligoric et al. & $\begin{array}{l}\text { Item-level } \\
\text { identification can } \\
\text { foster disruptive } \\
\text { innovation, } \\
\text { enabling CBMs. }\end{array}$ & $\begin{array}{l}\text { Proposal of a method } \\
\text { to facilitate IoT for } \\
\text { building a product } \\
\text { passport and support } \\
\text { data exchange, } \\
\text { enabling CE. }\end{array}$ & $\begin{array}{l}\text { SmartTags can be used in } \\
\text { CE for unique item-level } \\
\text { identification and } \\
\text { detection of } \\
\text { environmental } \\
\text { parameters. }\end{array}$ & $\begin{array}{l}\text { The solution is } \\
\text { evaluated according } \\
\text { to specific hypotheses. } \\
\text { Focus only on IoT. }\end{array}$ & $\begin{array}{l}\text { Need for further } \\
\text { research to test all } \\
\text { the hypotheses. }\end{array}$ \\
\hline [95] & $\begin{array}{l}\text { Ingemarsdotter } \\
\text { et al. }\end{array}$ & $\begin{array}{l}\text { IoT contributes to } \\
\text { CE transition, but } \\
\text { little is known } \\
\text { on practical } \\
\text { implementations. }\end{array}$ & $\begin{array}{c}\text { Analysis on how } \\
\text { companies implement } \\
\text { IoT for CE strategies } \\
\text { based on } \\
\text { secondary data. } \\
\text { Confront of the } \\
\text { implementations with } \\
\text { the opportunities } \\
\text { described in } \\
\text { the literature. }\end{array}$ & $\begin{array}{l}\text { IoT entails capabilities as } \\
\text { tracking, monitoring, } \\
\text { control, optimization. } \\
\text { Current implementations } \\
\text { of IoT-enabled CE mainly } \\
\text { target efficiency in use and } \\
\text { product life extension. }\end{array}$ & $\begin{array}{c}\text { Exclusion of } \\
\text { prototypes and } \\
\text { start-up companies } \\
\text { from the analysis. } \\
\text { Findings based only } \\
\text { on secondary data. } \\
\text { Literature review } \\
\text { limitations, as the } \\
\text { exclusion of low cited } \\
\text { contributions. } \\
\text { Focus only on IoT. }\end{array}$ & $\begin{array}{l}\text { Future studies should } \\
\text { include additional } \\
\text { cases in to increase } \\
\text { the robustness of the } \\
\text { results; in-depth case } \\
\text { studies with } \\
\text { companies would } \\
\text { be relevant. }\end{array}$ \\
\hline [96] & Kerin \& Pham & $\begin{array}{l}\text { Remanufacturing is } \\
\text { an important part } \\
\text { of a CE, but a } \\
\text { specific focus on } \\
\text { I4.0 supporting } \\
\text { remanufacturing } \\
\text { is missing. }\end{array}$ & $\begin{array}{l}\text { Review of the } \\
\text { literature on the } \\
\text { applicability of IoT, } \\
\text { VR and AR in } \\
\text { remanufacturing. }\end{array}$ & $\begin{array}{l}\text { Identification of } 29 \\
\text { research topics requiring } \\
\text { further investigation. } \\
\text { Greater automation is } \\
\text { required in manufacturing } \\
\text { process to apply I4.0. }\end{array}$ & $\begin{array}{l}\text { Focus only on } \\
\text { remanufacturing and on } \\
\text { IoT, VR, AR. }\end{array}$ & n.a. \\
\hline [97] & Moreno et al. & $\begin{array}{l}\text { The debate on } \\
\text { redistributed } \\
\text { manufacturing } \\
\text { (RDM) } \\
\text { examined potential } \\
\text { environmental } \\
\text { impacts, but there is } \\
\text { the need to } \\
\text { understand the } \\
\text { potential of RDM as } \\
\text { an enabler of CE. }\end{array}$ & $\begin{array}{l}\text { Exploration of DTs } \\
\text { potential for RDM as } \\
\text { an enabler of CE in } \\
\text { the consumer } \\
\text { goods industry. } \\
\text { Investigation through } \\
\text { multiple case studies. } \\
\text { Evaluation of the } \\
\text { Discrete Event } \\
\text { Simulation as a tool to } \\
\text { assess CE scenarios. }\end{array}$ & $\begin{array}{l}\text { Identification of several } \\
\text { opportunities for CE } \\
\text { through the } \\
\text { implementations of DTs. } \\
\text { Overall, the redistribution } \\
\text { of industrial systems } \\
\text { could benefit from the } \\
\text { CE transition. }\end{array}$ & $\begin{array}{l}\text { Findings based only } \\
\text { on secondary data } \\
\text { and in a specific } \\
\text { context of } \\
\text { investigation, } \\
\text { with precise } \\
\text { assumptions. } \\
\text { Focus only on } \\
\text { remanufacturing. }\end{array}$ & $\begin{array}{l}\text { Need for further } \\
\text { research releasing } \\
\text { the assumptions. } \\
\text { Future research } \\
\text { should focus on the } \\
\text { evaluation of the } \\
\text { economic and } \\
\text { environmental } \\
\text { impacts of the CE } \\
\text { opportunities } \\
\text { investigated. }\end{array}$ \\
\hline [98] & $\begin{array}{l}\text { Nascimento } \\
\text { et al. }\end{array}$ & $\begin{array}{l}\text { I4.0 can increase the } \\
\text { productivity of a } \\
\text { recycling factory } \\
\text { and optimize the } \\
\text { management of } \\
\text { workflows in the } \\
\text { entire value chain } \\
\text { from a CE } \\
\text { perspective. }\end{array}$ & $\begin{array}{l}\text { Exploration of how } \\
\text { I4.0 technologies can } \\
\text { enable CBM focused } \\
\text { on the reuse/recycle } \\
\text { of material. } \\
\text { Proposal of a } \\
\text { conceptual framework } \\
\text { for evaluating the } \\
\text { synergies, validated } \\
\text { through a focus group. }\end{array}$ & $\begin{array}{l}\text { Provision of } \\
\text { recommendations for } \\
\text { CBMs to reuse scrap } \\
\text { integrating web } \\
\text { technologies, reverse } \\
\text { logistics and AM. }\end{array}$ & $\begin{array}{l}\text { Possible bias and } \\
\text { subjectivity in } \\
\text { the validation. } \\
\text { Generalizability of the } \\
\text { study limited by the } \\
\text { specific sample } \\
\text { of experts. }\end{array}$ & n.a. \\
\hline [99] & Pham et al. & $\begin{array}{l}\text { Potentials to } \\
\text { combine I } 4.0 \text { and } \\
\text { CE to enhance the } \\
\text { sustainability of } \\
\text { manufacturing } \\
\text { sectors. }\end{array}$ & $\begin{array}{l}\text { Exploration of the I4.0 } \\
\text { factors accelerating the } \\
\text { sharing economy. } \\
\text { Investigation through } \\
\text { a case of electric } \\
\text { scooters in Taiwan. }\end{array}$ & $\begin{array}{l}\text { I4.0 is an enabler for } \\
\text { sharing economy. } \\
\text { I4.0 technologies are } \\
\text { helpful to overcome } \\
\text { specific barriers to } \\
\text { CE adoption. }\end{array}$ & $\begin{array}{l}\text { Generalizability of the } \\
\text { study limited by the } \\
\text { specific context } \\
\text { investigated. } \\
\text { Focus only on IoT } \\
\text { and CLOUD. }\end{array}$ & $\begin{array}{c}\text { Need to approach CE } \\
\text { with a holistic, } \\
\text { policy-oriented } \\
\text { approach. }\end{array}$ \\
\hline
\end{tabular}


Table 3. Cont.

\begin{tabular}{|c|c|c|c|c|c|c|}
\hline Ref. & Authors & $\begin{array}{l}\text { Context and } \\
\text { Motivation }\end{array}$ & Main Contribution & Main Findings & Main Limitations & $\begin{array}{l}\text { Main Future } \\
\text { Research }\end{array}$ \\
\hline [100] & $\begin{array}{c}\text { Rajput \& } \\
\text { Singh }\end{array}$ & $\begin{array}{l}\text { An integrated } \\
\text { I4.0-CE approach } \\
\text { can increase } \\
\text { efficiency and } \\
\text { optimize the entire } \\
\text { value chain. Thanks } \\
\text { to I4.0, possible } \\
\text { technological } \\
\text { barriers to the CE } \\
\text { transition might } \\
\text { be overcome. }\end{array}$ & $\begin{array}{c}\text { Identification of I4.0 } \\
\text { barriers to CE. } \\
\text { Prioritization of } \\
\text { barriers and } \\
\text { identification of } \\
\text { contextual } \\
\text { relationships among } \\
\text { them through } \\
\text { Interpretive Structural } \\
\text { Modelling. }\end{array}$ & $\begin{array}{c}\text { The main barriers are } \\
\text { process digitalization, } \\
\text { sensor technology and } \\
\text { design challenges. } \\
\text { An I4.0-CE approach } \\
\text { would allow operations } \\
\text { management } \\
\text { sustainability, optimizing } \\
\text { production and } \\
\text { consumption, while also } \\
\text { providing opportunities } \\
\text { for customization. }\end{array}$ & $\begin{array}{l}\text { Possible bias and } \\
\text { subjectivity in the } \\
\text { identification of } \\
\text { contextual } \\
\text { relationships. } \\
\text { No investigation of } \\
\text { specific DTs. }\end{array}$ & $\begin{array}{c}\text { Future research } \\
\text { should provide more } \\
\text { detailed and } \\
\text { empirical evidence } \\
\text { on barriers. }\end{array}$ \\
\hline
\end{tabular}

Identification of 26 drivers

Exploring connections and 15 barriers.
between CE and I4.0 in

enablers connecting $\mathrm{CE}$

and I4.0 in supply chains

are AI, Service and Policy

Framework, and CE;

the most significant

challenges are Interface

Designing and Automated

Synergy Model.

are factorized through

Principal Component Analysis.

Digital
transformation
enables the CE

investigation.
[102] Riesener et al. $\begin{gathered}\text { enables the CE } \\ \text { transition, but how } \\ \text { DTs can act } \\ \text { as enabler }\end{gathered}$

needs further

Proposal for a
framework

framework comprising

9 success factors for CE

transition, based on

digital transformation

$$
\text { technologies. }
$$

Identification of

systems and methods used in waste

I4.0 are

[103] Sarc et al.

implemented in the

field of waste

management to

achieve $\mathrm{CE}$. management sector

and of technologies

applied in other

sectors that could be

relevant as well.

Identification of the most prolific

technologies enabling

Discussion on the

requirements and

barriers for a successful

identified digital solutions.
$\mathrm{CE}$ at different levels.

implementation of

\section{Identification of the linkages between the phases of a product lifecycle and the design levels of business engineering.}

Future research should provide more detailed and

Focus only on SCM. empirical evidence on barriers and adoption of I4.0 technologies.
Robotic-based sorting and

lifting systems in waste

management are pivotal,

as they also partially replace humans.

Limitations can be identified, material- and technology-wise.
Several possibilities for

DTs software supporting

$\mathrm{CE}$ are identified at the micro-level.

The need for cooperation,

networking and data

management at the

meso-level is stressed.

Blockchain technologies

play a pivotal role but

concerns on data

ownership are unsolved.

$\mathrm{CE}$ is not easy to achieve at a macro-level.

Identification of several opportunities for

digitalization supporting

CE transition,

as virtualization.

collaboration with

stakeholders, and digital

collaboration platforms

are pivotal for enabling

CBMs, and can be fostered by blockchain.
Limitation related to the experts' judgments. possible biased of
Future research should better investigate the different success factors.
Results are conceptual and based on available literature.
Need for case-based empirical research on digital solutions and their effects on $\mathrm{CE}$ on each level.
Description of how the application of IoT and big data, could support CBMs during the entire product life cycle.

The need to involve the entire supply chain for proper implementation should address the sensors needed for a
successful application

of I 4.0 for waste

management.
Future research
Gap between the implementation.

[105] Bianchini et al.
Proposal of a model linking the adoption of $\mathrm{T}$ and big data to CBMs.

Digital transforma-
tion can support CE in tackling the specific issue.
Discussion over the

model through
literature cases.
Future research should provide more detailed and empirical evidence. is underlined. 
Table 3. Cont.

\begin{tabular}{|c|c|c|c|c|c|c|}
\hline Ref. & Authors & $\begin{array}{l}\text { Context and } \\
\text { Motivation }\end{array}$ & Main Contribution & Main Findings & Main Limitations & $\begin{array}{l}\text { Main Future } \\
\text { Research }\end{array}$ \\
\hline [106] & Bressanelli et al. & $\begin{array}{l}\text { DTs are key } \\
\text { enablers for the } \\
\text { introduction of } \\
\text { servitized business } \\
\text { models and CE, } \\
\text { but more } \\
\text { investigations } \\
\text { are needed. }\end{array}$ & $\begin{array}{l}\text { Development of a } \\
\text { conceptual framework, } \\
\text { based on the literature } \\
\text { and a case study, } \\
\text { focusing on the } \\
\text { enabling role of IoT } \\
\text { and BDA. }\end{array}$ & $\begin{array}{c}\text { Identification of } 8 \\
\text { functionalities enabled by } \\
\text { IoT and BDA; } \\
\text { investigation of their } \\
\text { effects on CE. } \\
\text { The results highlight that } \\
\text { to move towards CE, } \\
\text { companies should couple } \\
\text { IoT with BDA. }\end{array}$ & $\begin{array}{l}\text { Findings based only } \\
\text { on one case study, so } \\
\text { the generalizability } \\
\text { is limited. } \\
\text { Focus only on IoT } \\
\text { and BDA. }\end{array}$ & $\begin{array}{l}\text { Need for empirically } \\
\text { investigating a } \\
\text { larger sample. } \\
\text { Future research } \\
\text { should focus on } \\
\text { other DTs. }\end{array}$ \\
\hline [107] & Bressanelli et al. & $\begin{array}{c}\text { Product-Service } \\
\text { Systems (PSS) } \\
\text { promote } \\
\text { sustainability and } \\
\text { CE. DTs enable PSS, } \\
\text { but more details are } \\
\text { needed on their } \\
\text { relationships. }\end{array}$ & $\begin{array}{l}\text { Exploration of the role } \\
\text { of DTs in enabling PSS. } \\
\text { Analysis through a } \\
\text { case study of a firm } \\
\text { leveraging IoT } \\
\text { and BDA. }\end{array}$ & $\begin{array}{l}\text { IoT and BDA are relevant } \\
\text { and help firms } \\
\text { overcoming challenges } \\
\text { (as operational risks, } \\
\text { technology improvement, } \\
\text { return flow uncertainties), } \\
\text { through } 4 \text { digitally } \\
\text { enabled functionalities. }\end{array}$ & $\begin{array}{l}\text { Findings based only } \\
\text { on one case study, so } \\
\text { the generalizability } \\
\text { is limited. } \\
\text { Focus only on IoT } \\
\text { and BDA. }\end{array}$ & $\begin{array}{l}\text { Need for empirically } \\
\text { investigation of a } \\
\text { larger sample. } \\
\text { Future research } \\
\text { should focus on } \\
\text { other DTs. }\end{array}$ \\
\hline [17] & $\begin{array}{l}\text { Lopes de } \\
\text { Sousa } \\
\text { Jabbour et al. }\end{array}$ & $\begin{array}{l}\text { DTs can unlock the } \\
\text { circularity of } \\
\text { resources within } \\
\text { supply chains, } \\
\text { but linkages } \\
\text { between CE and } \\
\text { I4.0 need to be } \\
\text { better explored. }\end{array}$ & $\begin{array}{l}\text { Proposal of a roadmap } \\
\text { to enhance the } \\
\text { application of CE } \\
\text { principles in firms } \\
\text { through } 14.0 .\end{array}$ & $\begin{array}{l}\text { Discussion over mutual } \\
\text { I4.0-CE relationships. } \\
\text { Understanding of the } \\
\text { potential contributions of } \\
\text { technologies to the } \\
\text { ReSOLVE framework. } \\
\text { Outline of a research } \\
\text { agenda for the integration } \\
\text { of I4.0 and CE. }\end{array}$ & $\begin{array}{l}\text { Results are } \\
\text { conceptual. } \\
\text { Focus only on recycling } \\
\text { and IoT, CLOUD, AM. }\end{array}$ & $\begin{array}{l}\text { Need for empirical } \\
\text { research for } \\
\text { operationalizing the } \\
\text { proposed framework. } \\
\text { Further research } \\
\text { should consider } \\
\text { in-depth case studies. }\end{array}$ \\
\hline [108] & Makarova et al. & $\begin{array}{l}\text { Reverse logistics is } \\
\text { pivotal in the } \\
\text { CE transition. } \\
\text { The planning of the } \\
\text { reverse logistics is } \\
\text { difficult, but I4.0 } \\
\text { can support it. }\end{array}$ & $\begin{array}{l}\text { Description of } \\
\text { industrial } \\
\text { development in the CE } \\
\text { transition and new } \\
\text { trends in the } \\
\text { development } \\
\text { of logistics. }\end{array}$ & $\begin{array}{l}\text { Proposal for a system } \\
\text { allowing the planning and } \\
\text { organization of processes, } \\
\text { so to minimize raw } \\
\text { materials' consumption } \\
\text { and reduce negative } \\
\text { environmental impacts. }\end{array}$ & Focus only on SCM. & $\begin{array}{l}\text { Future research } \\
\text { should focus on } \\
\text { simulation models for } \\
\text { the adoption of the } \\
\text { proposed system. }\end{array}$ \\
\hline [109] & Neligan & $\begin{array}{c}\text { Opportunities and } \\
\text { challenges of } \\
\text { digitalization for } \\
\text { CE transition need } \\
\text { investigation. }\end{array}$ & $\begin{array}{l}\text { Empirical findings on } \\
\text { the importance of } \\
\text { digitalization to } \\
\text { improve material } \\
\text { efficiency in the } \\
\text { German industry. }\end{array}$ & $\begin{array}{l}\text { Opportunities deriving } \\
\text { from DTs are limitedly } \\
\text { exploited and addressed } \\
\text { primarily to improve } \\
\text { efficiency in the } \\
\text { manufacturing process. }\end{array}$ & $\begin{array}{l}\text { Generalizability of the } \\
\text { study limited by the } \\
\text { specific context } \\
\text { investigated. } \\
\text { No investigation of } \\
\text { specific DTs. }\end{array}$ & $\begin{array}{c}\text { Future research } \\
\text { should focus on } \\
\text { barriers and drivers } \\
\text { to the CE transition, } \\
\text { while also evaluating } \\
\text { the economic benefit } \\
\text { from the adoption of } \\
\text { DTs and CE. }\end{array}$ \\
\hline [21] & Okorie et al. & $\begin{array}{l}\text { Opportunities to } \\
\text { apply the CE to the } \\
\text { rapidly changing } \\
\text { paradigm of I4.0 } \\
\text { need investigation. }\end{array}$ & $\begin{array}{l}\text { Systematic review of } \\
\text { the empirical literature } \\
\text { related to DTs, I4.0, } \\
\text { and circular } \\
\text { approaches. }\end{array}$ & $\begin{array}{c}\text { Proposal for an integrative } \\
\text { CE-DT framework based } \\
\text { on Technology life } \\
\text { cycle (TLC). }\end{array}$ & $\begin{array}{l}\text { Systematic protocol } \\
\text { limitations. } \\
\text { Specific limitations } \\
\text { related to the use } \\
\text { of TLC. } \\
\text { No investigation of } \\
\text { specific DTs nor specific } \\
\text { CE aspects. }\end{array}$ & $\begin{array}{c}\text { Future research } \\
\text { should focus on BDA } \\
\text { and a holistic } \\
\text { approach to } \\
\text { stakeholders. } \\
\text { Need to examine the } \\
\text { methods employed in } \\
\text { CE-I4.0 research. }\end{array}$ \\
\hline [16] & $\begin{array}{l}\text { Nobre \& } \\
\text { Tavares }\end{array}$ & $\begin{array}{l}\text { Technologies as IoT } \\
\text { and BDA can } \\
\text { leverage the } \\
\text { adoption of CE. It is } \\
\text { fundamental to } \\
\text { understand the } \\
\text { current debate on } \\
\text { the integration of } \\
\text { the concepts. }\end{array}$ & $\begin{array}{l}\text { Bibliometric study on } \\
\text { the application of big } \\
\text { data/IoT within the } \\
\text { context of CE. }\end{array}$ & $\begin{array}{l}\text { A disconnection between } \\
\text { industry initiatives and } \\
\text { scientific research } \\
\text { is highlighted. } \\
\text { Specific contexts in terms } \\
\text { of geographic area, } \\
\text { economy and greenhouse } \\
\text { gas emissions could have } \\
\text { a higher interest in CE } \\
\text { than what shown by the } \\
\text { analysis of publication. }\end{array}$ & $\begin{array}{l}\text { Systematic protocol } \\
\text { limitations (timespan). } \\
\text { Focus only on IoT } \\
\text { and BDA. }\end{array}$ & $\begin{array}{l}\text { Future research } \\
\text { should focus on } \\
\text { exploratory and } \\
\text { practical studies. }\end{array}$ \\
\hline [110] & $\begin{array}{c}\text { Pagoropoulos } \\
\text { et al. }\end{array}$ & $\begin{array}{l}\text { Both CE and DTs } \\
\text { are facing rapid } \\
\text { proliferation. }\end{array}$ & $\begin{array}{l}\text { Systematic literature } \\
\text { review on how DTs can } \\
\text { support CBMs. }\end{array}$ & $\begin{array}{l}\text { Identification of 7 DTs. } \\
\text { DTs support the CE } \\
\text { transition optimizing } \\
\text { material flows. } \\
\text { A lack of empirical studies } \\
\text { is highlighted. }\end{array}$ & $\begin{array}{l}\text { Systematic protocol } \\
\text { limitations. } \\
\text { No investigation of } \\
\text { specific DTs nor specific } \\
\text { CE aspects. }\end{array}$ & $\begin{array}{c}\text { Future research } \\
\text { should provide more } \\
\text { detailed and } \\
\text { empirical evidence. }\end{array}$ \\
\hline [111] & $\begin{array}{l}\text { Moreno \& } \\
\text { Charnley }\end{array}$ & $\begin{array}{l}\text { Redistributed } \\
\text { manufacturing and } \\
\text { CE can potentially } \\
\text { disrupt current } \\
\text { models of } \\
\text { consumer goods } \\
\text { production and } \\
\text { consumption. }\end{array}$ & $\begin{array}{l}\text { Exploration of digital } \\
\text { intelligence and } \\
\text { redistributed } \\
\text { manufacturing as } \\
\text { enablers of CE. } \\
\text { Analysis of literature } \\
\text { case studies. }\end{array}$ & $\begin{array}{l}\text { The integration of DTs can } \\
\text { enable the distribution of } \\
\text { knowledge, customization } \\
\text { and CBMs. } \\
\text { Circular innovations } \\
\text { support more regenerative } \\
\text { and resilient systems of } \\
\text { production and } \\
\text { consumption. }\end{array}$ & $\begin{array}{l}\text { Findings based only } \\
\text { on secondary data. } \\
\text { No investigation of } \\
\text { specific DTs nor specific } \\
\text { CE aspects. }\end{array}$ & $\begin{array}{l}\text { Need for } \\
\text { empirical research } \\
\text { to further validate } \\
\text { the findings. }\end{array}$ \\
\hline
\end{tabular}


Table 3. Cont.

\begin{tabular}{|c|c|c|c|c|c|c|}
\hline Ref. & Authors & $\begin{array}{l}\text { Context and } \\
\text { Motivation }\end{array}$ & Main Contribution & Main Findings & Main Limitations & $\begin{array}{l}\text { Main Future } \\
\text { Research }\end{array}$ \\
\hline$[112]$ & Reuter & $\begin{array}{l}\text { Process metallurgy } \\
\text { support CE; } \\
\text { the digitalizing of } \\
\text { the material } \\
\text { production } \\
\text { could provide } \\
\text { additional support. }\end{array}$ & $\begin{array}{l}\text { Evaluation of the } \\
\text { different possibilities } \\
\text { and application for the } \\
\text { metallurgical IoT. }\end{array}$ & $\begin{array}{l}\text { Identification of } \\
\text { opportunities, limits, tools, } \\
\text { and methods of process } \\
\text { metallurgy and recycling } \\
\text { within the CE, through the } \\
\text { adoption of DTs. }\end{array}$ & $\begin{array}{l}\text { Generalizability of the } \\
\text { study limited by the } \\
\text { specific context } \\
\text { investigated. } \\
\text { Focus only on IoT } \\
\text { and BDA. }\end{array}$ & $\begin{array}{l}\text { Future research } \\
\text { should focus, } \\
\text { among the others, } \\
\text { on the role of the } \\
\text { disruptive CBMs. }\end{array}$ \\
\hline
\end{tabular}

\subsection{Digital Technologies Enabling the ReSOLVE Framework}

A narrow group of contributions investigated the relationship between the DTs and the overall ReSOLVE framework (Figure 10). The contributions were mainly review or conceptual papers. They considered one DT or a limited set of them, paving the path for more integrated analyses. From this perspective, Nobre and Tavares [80] linked some aspects related to IoT and BDA to the different areas of action of the framework. $\mathrm{BDA}$ and their requirements for appropriate applications in the different areas were also discussed [55]. IoT was also considered together with CLOUD and AM [15,17], and a framework for fostering their adoption was also proposed. Lastly, different examples of CYB applications in the ReSOLVE framework, focusing particularly on the benefits related to traceability and security, have been provided [75]; however, the proposed applications were still at a pilot or planning stage.

The reviewed contributions are nonetheless mostly focused on specific $\mathrm{CE}$ aspects associated with the ReSOLVE action areas (Table 1).

\subsubsection{DTs Enabling the Regenerate Area}

The Regenerate area has been so far connected to a limited series of DTs (Figure 10). Regenerate area could benefit from DTs thanks to the application of IoT in the form of sensors for the collection of data and BDA for the elaboration of the collected data [17]. A decisive positive impact of IoT on the product lifetime extension is underlined in terms of monitoring, control and optimization, allowing additional support and value to the customer [95]. As a part of IoT, the use of Smart Tags for building a product passport and enabling data sharing and exchanging is supported [94]. The use of BDA is then necessary for a proper elaboration and use of such data, facilitating the decision-making process [89]. Riesener et al. [102] detailed different phases of the lifecycle, namely manufacturing, usage and reutilization/recycling. As for the manufacturing phase, CBY, IoT and HVSYS can help to solve information asymmetry; concerning the usage phase, $\mathrm{CYB}$ and particularly blockchain might support the handover to different customers, also enabling the traceability of the product and the acquisition and verification of related data [115]. Regarding the reutilization/recycling phase, BDA might allow different cycles, fostering a reverse logistics system and waste management [116].

\subsubsection{DTs Enabling the Share Area}

The research over the use of DTs in support of the Share area appears rather limited (Figure 10). IoT allows the monitoring and tracking of the use and condition of products, thus enabling reuse [95]. As a large amount of data would be collected, BDA and CYB become again of fundamental importance to manage the complexity [102]. The collection of data on the product condition and the related decisions for reuse would allow better cooperation among the tiers of the value chain $[66,89]$.

\subsubsection{DTs Enabling the Optimize Area}

The enabling role of different DTs in terms of Optimize area received rather good attention (Figure 10). Nonetheless, despite evidence that DTs can support resource efficiency [12,66], firms still lag as for DTs adoption and exploitation [109]. A pivotal role is played by IoT for monitoring, control and optimization [95], allowing also the iden- 
tification of resource waste in real-time [92]. The IoT would then require the support of BDA [102,112]. Nonetheless, the collection and analysis of data could be insufficient, and the use of CYB is suggested to share the product information among the different stakeholders, while also facilitating the paperwork activities and the checking of the status of the products along the supply chain [69].

From a general perspective, the role of DTs is also studied concerning supply chain management [101]. As the management of inbound and outbound logistics is particularly relevant, firms might benefit from DTs applications in procurement and logistics, also helping build the capabilities needed for collecting, processing and sharing information $[62,63]$. From a practical viewpoint, IoT can allow the real-time evaluation of the product value along the tiers [78], with an exchange of the data stored in a CLOUD inventory [88,93].

DTs could also support reverse logistics, with a particular relevance of BDA, on data collected with an HVSYS perspective [108], possibly fostered by AM production system [68]. The transparency and security of data exchange and any type of digital transactions can be guaranteed by the use of CYB; from a larger perspective, the use of CYB could also support supply chains in making their practices more transparent, secure and correct [54,61]. Possible different configuration scenarios can be then analyzed thanks to SIM [97]. As a last remark, preliminary insights on the combined support from DTs and CE to enhance sustainability started being discussed [61,88].

\subsubsection{DTs Enabling the Loop Area}

The Loop area can benefit from the adoption of different DTs (Figure 10). Particularly, a good variety of DTs proves to foster actions related to the disassembly of products. An interesting role is played by AR, which could be useful in planning the disassembly sequence, as it would allow the visualization of all the information and equipment needed in the process, besides helping in training operators [96]. ROBs also have an interesting role in the disassembly process [85], although issues in terms of economic feasibility may pose limitations [83]. As for the determining and optimizing of the disassembly process, both SIM [85,91] and BDA for mining a repository of disassembly processes [70] are considered as possible options.

The remanufacturing process requires different data related to the product, i.e., its status, maintenance history, disassembly and reassembly [117]. From this perspective, the use of IoT via sensors would be helpful to track the product history, through real-time monitoring that could bring positive effects in different processes [89,118]. However, although few cases can be spotted where IoT is relevant for looping strategies, empirical studies show that IoT is not largely used for product remanufacturing [95]. Additional opportunities have been conceptualized from the integrated use of IoT and AM, but the realization has not been demonstrated [68]. AM nonetheless can contribute to sustainability, presenting lower cost related for example to set-up, and can play an important role in the loop area when the workload is distributed along the different tiers of the supply chain [68,119]. For the latter point, the use of an HVSYS would allow real-time data management throughout the entire chain, thus facilitating the loop strategies [68]. Lastly, SIM can assist remanufacturing processes, as discrete event simulation models are essential to determine the quality of a product [91].

As for the recycling process, IoT would provide benefits in terms of monitoring and tracking [103], enabling looping [71,95]. Two relevant aspects emerged as connected to the adoption of IoT: first, to make proper decisions, data should be collected with an HVSYS perspective [74]; second, as many data would be collected, BDA becomes fundamental to manage the complexity [102]. Lastly, the use of ROB would facilitate the recycling process, while also bringing benefits from a social sustainability perspective [103]. Additional insights are provided highlighting a strong correlation between the adoption of recycling practices and the adoption of $\mathrm{BDA}, \mathrm{ROB}$ and $\mathrm{AM}$, suggesting also that I4.0 might allow greater integration among the partners of the value chain [66]. Nonetheless, several issues emerge trying to link the concept of $\mathrm{CE}$ with the one related to industrial 
systems; incorporating CE into industrial networks requires a change in the economic paradigm [120] that would be allowed only by a strong willingness of all the involved partners to embark in this transition [121]. The main obstacle and critical resource for the transition is the trust among the partners [122], which becomes even more pivotal if the transition is enabled by DTs [123]. Additionally, moving from a single firm to the value chain and then the industrial system would require the identification of the best set of DTs to use [124].

\subsubsection{DTs Enabling the Virtualize Area}

The enabling role of DTs towards the Virtualize areas has been so far investigated from a rather limited perspective (Figure 10). As for SMSER, the discourse has been approached from a general viewpoint, without much detail on specific DTs. Exact points have arisen in terms of the need of being able to collect data to monitor and evaluate the conditions of the product, using for example IoT [89], complemented with CLOUD [99] and DBA for the analysis [105]. Additionally, also AM can be interesting for the customization of products based on interactions among different tiers of the value chain [68]. The action area can be supported by IoT, as they could foster the relationship and communication between organizations, suppliers and customers [68].

\subsubsection{DTs Enabling the Exchange Area}

The area has been largely addressed mainly from a general, broad and theoretical perspective (Figure 10), understanding how the presence and adoption of new technologies could foster and support the transition towards new update CE practices. DTs could indeed offer a solution for core data records concerning a sustainable product and material database [79]. Opportunities can be found at different levels, as the optimization of the resources use, the engagement in business models enabled by software development, the share of information on a network level, the creation of infrastructures supporting the tracking and monitoring [104], while also fostering cleaner production [84]. Although so far, the discourse has been mainly theoretical, some first empirical applications can be found for specific CE aspects, as redistributed manufacturing [111].

Concerning specific DTs, the discourse mainly developed around the adoption of IoT and BDA $[16,67,77,112]$, with the latter playing a fundamental role also in terms of predictive analytics [64] with the support of CLOUD [67]. Positive impacts were also observed concerning AM, as it could easily support CE strategies focused on materials [76].

At this stage, contributions also focused on the identification of barriers and challenges to and for DIGIT $[67,100,104]$. Some of the barriers refer to organizational aspects (lack of competencies, need for coordination, need for technical development), to economic aspects (financial and operational risk), as well as the digitalization process itself. Particularly, the adoption of DTs can be strongly hindered by organizational resistance deriving from both the employees and the management, who can oppose the change within their organization [125] and might lack specific competence and skills [126]; particularly, the role of managers has been considered of fundamental importance to support the integration of DTs in the light of CE [12]. Additional challenges seem to emerge concerning the context of the investigation, with developed countries facing mainly issues related to the low maturity level of the desired technology [127] after national strategies and policy have been formulated [128], and the developing countries still struggling with the setting of proper standards and legislation [127]. Specific barriers in the context of emerging economies were indeed pointed out in terms of the macro environment [90]. Additionally, an important role is played by the availability of the technologies, also from an economic perspective [17]. In this scenario, it is pivotal to identify the best drivers to overcome the barriers [129].

\subsection{Digital Technologies Enabling the CE Transition: Further Insights}

According to the overview provided in Section 2.1, the ReSOLVE framework entails major circular business opportunities [27]. The literature has largely addressed the role of 
DTs as possible enablers of CBMs; however, the important operational role of the ReSOLVE framework has not been considered. For having an overview as complete as possible, we considered also this general viewpoint. From a broad perspective, DTs allow the industry to embrace innovative, productive and sustainable CBMs [86,105]. A central role is played by the exploitation of data [13] and consequently data collection, integration and analysis, using IoT, CLOUD and BDA [60]. DTs would also allow greater involvement of customers in the definition of CBMs [9], leading for example to customized services [97].

Analyzing specific DTs, IoT is undoubtedly among the pivotal ones: on the one hand, it can support the definition of servitized CBMs [73]; on the other hand, it can advance the tracking, monitoring and control of products $[73,95]$, favoring a real-time analysis of the product's residual value [78]. The adoption of IoT implies the need for a good quality of data and appropriate data management [73], so that BDA becomes fundamental [15,107]. Additionally, IoT and BDA together can support specific aspects at each product life cycle stage (as product design; marketing activities; monitoring and tracking of the product; technical support and maintenance; product optimized use, upgrade and renovation) [106]. To effectively adopt IoT and BDA, some aspects are necessary [72] such as (i) the collaboration with stakeholders and particularly customers to obtain the data, (ii) the capability of workers to analyze and manage the data and (iii) the consideration of impacts from a sustainability perspective, thus including economic and social aspects-given the high cost of DTs, and the strong relationship between product and customer satisfaction [130,131]. Lastly, within this framework, CLOUD is fundamental for the storage and share of data [87]. The literature also offers insights into the relationship between CBMs and AM as an enabler of CE. AM emerges as capable to increase productivity and manufacturing freedom on demand, targeting the needs of each customer, while also enhancing sustainability, with economic, environmental and social implications [98].

\section{Digital Technologies Enabling the CE Transition: Discussion and Open Issues}

The analysis of the literature confirmed the relevant role of DTs in enabling and supporting the CE transition. The trend in terms of year of publication (Figure 4) underlines how the research on the topic is relatively young, as also noted by previous research $[21,82,104]$. The geographical distribution of the authors is showing a global interest in the topic by both developing and developed countries (Figure 6), as also previously underlined [4]. The descriptive analysis of the different CE aspects (Figure 8) highlights how the research is still mainly focused on specific aspects of $\mathrm{CE}$, and it is not integrated into a more structured and operative framework, as the ReSOLVE one [16]. In this way, DTs are related to specific CE aspects or processes, and it is difficult to have a complete overview of all the benefits that DTs could bring to the overall CE transition (Figure 10). As also emerged from the descriptive analysis, the discourse is still mainly driven by theoretical contributions, and particularly literature reviews, so that advancement from both a conceptual and (mostly) an empirical perspective is strongly recommended (Figure 11). The urgency is also underlined by the breakthrough potential of the empirical research conducted on the topic (Figure 7). Particularly, considering the insights that emerged from the present review (see also Table 3), the following issues are worthy of note and urge for additional research efforts.

Integrated and holistic perspective on the DT-CE relationship. Shortcomings can be identified in the evaluation of the relationships between DTs and CE from both sides. Regarding DTs, the largest share of contributions focuses on one or a limited set of DTs (Figure 9), while the contributions addressing DTs in general terms mainly provide few examples on specific DTs or applications. Nonetheless, DTs are for their nature interconnected, and it may not be possible to adopt a DT without at least a partial presence of another one [104]. The research on the integration of the different DTs shows indeed a growth potential for better investigating their role in the CE transition $[48,110]$. As for $C E$, the literature is still mainly focused on specific CE aspects, not considering a more integrated approach (Figure 8). Although the literature largely recognized the enabling role of DTs, there is an ur- 
gency to investigate how they enable the transition from a more operative perspective [107], as the one offered by the ReSOLVE framework [16]. Additionally, as emerged from the review, specific ReSOLVE action areas and aspects of CE are more investigated than others (Figure 8), leaving ample room for additional research. To move towards enhanced $\mathrm{CE}$, firms should adopt CE practices. As DTs enable the CE transitions, it comes directly that DTs could also enable and support the adoption of specific CE practices. The investigation of the relationship should consider the intensity with which a specific DT could impact the $\mathrm{CE}$ transition, not only from an overall perspective but also regarding specific action areas and specific practices that a firm could implement-see, for example, [132]. Such analysis would make it easier for the industry to understand if, how and to what extent the adoption of specific DTs could impact the CE transition, possibly allowing them to better organize their resources and concentrate their efforts towards the adoption of those DTs that could be more efficacious.

The decision-making process. The CE practices would have to undergo an adoption process that could be influenced by several factors, as demonstrated for example for industrial sustainability $[58,130,133]$. The evaluation of these factors would be of fundamental importance to better understand how and to what extent DTs can enhance specific CE practices. In particular, a holistic investigation on the following points is advised, understanding their role in the different phases of the adoption process of CE practices, and how they could change according to the action of different DTs:

- Barriers to CE transition: identification and evaluation of the inhibitors of the adoption process [9,17];

- Drivers for $\mathrm{CE}$ transition: identification and evaluation of the fostering factors for the adoption process $[17,66]$;

- Performance measurement: identification and evaluation of the performance reached after the adoption; fundamental for this aspect would be the identification of how the performance could be gauged $[17,59]$. Another important aspect to consider is the evaluation of performance beyond the ones strictly related to CE. As introduced in the previous section, some authors started investigating the performance related to the overall sustainability derived from the adoption of CE practices supported by the DTs, see for example $[54,98,134]$. However, despite the common agreement, additional research seems to be necessary to better determine the relationship between DTs and industrial sustainability $[135,136]$;

- Contextual factors: identification of those contextual factors, as geographical area, sector or firm's size that could influence the adoption process [137] and that so far appear still limitedly investigated (see Section 4.4.); previous research showed a pivotal role of the firm's size, particularly when SMEs and LEs are confronted [138-140];

- Digital maturity level: evaluation of the impact of the digital maturity of the firm on the outcomes, as it might represent a quite important influence [98,141];

- CE management: evaluation of the impact of how CE is managed within the firm, as it might influence the outcomes [137]. For example, the presence of an environmental management system demonstrated to strongly support the CE transition [142]; as a clear predominance for a heterarchical control for DTs has been underlined [143,144], the debate on whether a centralized or decentralized system would be better for environmental-related aspects is still open [145,146].

Empirical research. As abovementioned and shown in the descriptive results (Figures 11 and 12) and highlighted by the in-depth analysis of the content (Table 3), the largest share of the published contributions employs a theoretical approach. This urges for more empirical research, which is also highlighted in previous literature $[15,77,87,110]$. Although an increase in empirical studies can be appreciated in the latest years (Table 2) [82], there is still ample room for providing practical demonstrations of the impact of DTs on the $\mathrm{CE}$ transition. To deepen the understanding of the relationships, the adoption of the case study methodology is suggested, providing more qualitative than quantitative evidence, but allowing a deeper analysis of the context under investigation [101,147] (see also Table 3). 
As some contributions employed the case study methodology, the investigations present less than five case studies, with the largest share of contributions focusing on one case study (Table 2; Figure 12). To confront an already existing theory toward an empirical application and structuring the theory in light of the observed results, a larger number of case studies is therefore suggested [148,149].

The role of industrial systems and stakeholders. Moving from a micro to a meso-level of analysis, DTs have been proven to facilitate the cooperation and connection of firms, foster industrial symbiosis and help build a collaborative environment to promote the CE [104]. Regardless of the provided insights on the possible influence of DTs on SCM, it is suggested to conduct specific studies investigating industrial systems from the perspective of all the involved firms, not only a focal/single one [131,150] (see also Table 3).

\section{Conclusions}

The present study critically reviewed the literature on the role of DTs in operationalizing the CE transition, shaping the analysis according to the ReSOLVE framework.

Our analysis indicates a broad focus on the topic, yet there is still the need to tackle it in a more integrated and holistic manner. The discourse is mainly focused on single DTs enabling specific CE aspects; thus, it is tough to have a complete view of all the possible DT implications on the overall CE transition and operatively address the transition itself. From this perspective, the paper suggests interesting directions for further research, aimed at addressing the operationalization of CE through DTs, with an integrated and holistic perspective.

The present study offers contributions from both theoretical and managerial viewpoints. First, we analyzed 66 literature contributions using a comprehensive list of axes for the evaluation: these axes could be useful for scholars and managers alike as a reference guide to continue the exploration of the topic. Second, we provided an analysis of the previous literature according to the axes of evaluation, spurring interest in future research. Third, we suggested the need for additional research on the topic; such research should provide a more integrated and holistic view on the topic itself, supported by strong empirical evidence. Leveraging on this, further research from academia is fostered, so to support practitioners in understanding the best manner to exploit the enabling potential of DTs.

We conducted our analysis following the principles of ethic, quality and accuracy. Nonetheless, some limitations should be highlighted. First, we conducted our study considering only Scopus as a scientific research database, and different findings may be obtained using other databases. Second, as the role of DTs as an enabler of CE is a current hot topic in the managerial and academic debate, the number of studies on the argument is constantly increasing, and the specific time frame we used could have excluded some relevant recent contributions. Future research should be thus directed to consider the abovementioned limitations, while also investigating the evolution of the research topic.

Author Contributions: Conceptualization, E.C., A.N. and M.N.; methodology, A.N. and M.N.; validation, E.C., A.N. and M.N.; formal analysis, A.N., M.N., C.A.B. and T.L.; writing-original draft preparation, A.N.; writing-review and editing, E.C., A.N. and M.N.; visualization, A.N.; supervision, A.N.; project administration, A.N. All authors have read and agreed to the published version of the manuscript.

Funding: This research received no external funding.

Conflicts of Interest: The authors declare no conflict of interest

\section{References}

1. United Nations. Transforming Our World: The 2030 Agenda for Sustainable Development; 2015. Available online: https:// sustainabledevelopment.un.org/post2015/transformingourworld (accessed on 4 March 2021).

2. European Commission. The European Green Deal; 2019. Available online: https://eur-lex.europa.eu/legal-content/EN/TXT/ PDF / ?uri=CELEX:52019DC0640\&from=EN (accessed on 4 March 2021). 
3. Dantas, T.E.T.; de-Souza, E.D.; Destro, I.R.; Hammes, G.; Rodriguez, C.M.T.; Soares, S.R. How the combination of Circular Economy and Industry 4.0 can contribute towards achieving the sustainable development goals. Sustain. Prod. Consum. 2021, 26, 213-227. [CrossRef]

4. Cioffi, R.; Travaglioni, M.; Piscitelli, G.; Petrillo, A.; Parmentola, A. Smart manufacturing systems and applied industrial technologies for a sustainable industry: A systematic literature review. Appl. Sci. 2020, 10, 2897. [CrossRef]

5. Alamerew, Y.A.; Brissaud, D. Circular economy assessment tool for end of life product recovery strategies. J. Remanuf. 2019, 9, 169-185. [CrossRef]

6. Kirchherr, J.; Reike, D.; Hekkert, M. Conceptualizing the circular economy: An analysis of 114 definitions. Resour. Conserv. Recycl. 2017, 127, 221-232. [CrossRef]

7. Helander, H.; Petit-Boix, A.; Leipold, S.; Bringezu, S. How to monitor environmental pressures of a circular economy: An assessment of indicators. J. Ind. Ecol. 2019, 23, 1278-1291. [CrossRef]

8. Fonseca, L.; Domingues, J.; Pereira, M.; Martins, F.; Zimon, D. Assessment of circular economy within portuguese organizations. Sustainability 2018, 10, 2521. [CrossRef]

9. Massaro, M.; Secinaro, S.; Dal Mas, F.; Brescia, V.; Calandra, D. Industry 4.0 and circular economy: An exploratory analysis of academic and practitioners' perspectives. Bus. Strateg. Environ. 2021, 30, 1213-1231. [CrossRef]

10. Büchi, G.; Cugno, M.; Castagnoli, R. Smart factory performance and Industry 4.0. Technol. Forecast. Soc. Chang. 2020, 150, 119790. [CrossRef]

11. Ardito, L.; Petruzzelli, A.M.; Panniello, U.; Garavelli, A.C. Towards Industry 4.0: Mapping digital technologies for supply chain management-marketing integration. Bus. Process Manag. J. 2019, 25, 323-346. [CrossRef]

12. Chauhan, C.; Sharma, A.; Singh, A. A SAP-LAP linkages framework for integrating Industry 4.0 and circular economy. Benchmarking Int. J. 2019. [CrossRef]

13. Antikainen, M.; Uusitalo, T.; Kivikytö-Reponen, P. Digitalisation as an enabler of circular economy. Procedia CIRP 2018, 73, 45-49. [CrossRef]

14. Rüßmann, M.; Lorenz, M.; Gerbert, P.; Waldner, M.; Justus, J.; Engel, P.; Harnisch, M. Industry 4.0: The future of productivity and growth in manufacturing industries. BCG Perspect. 2015. [CrossRef]

15. Ghoreishi, M.; Happonen, A. New promises AI brings into circular economy accelerated product design: A review on supporting literature. E3S Web Conf. 2020, 158, 06002. [CrossRef]

16. Nobre, G.C.; Tavares, E. Scientific literature analysis on big data and internet of things applications on circular economy: A bibliometric study. Scientometrics 2017, 111, 463-492. [CrossRef]

17. Lopes de Sousa Jabbour, A.B.; Jabbour, C.J.C.; Godinho Filho, M.; Roubaud, D. Industry 4.0 and the circular economy: A proposed research agenda and original roadmap for sustainable operations. Ann. Oper. Res. 2018, 270, 273-286. [CrossRef]

18. Saidani, M.; Yannou, B.; Leroy, Y.; Cluzel, F.; Kendall, A. A taxonomy of circular economy indicators. J. Clean. Prod. 2019, 207, 542-559. [CrossRef]

19. Angioletti, C.M.; Despeisse, M.; Rocca, R. Product circularity assessment methodology cecilia. IFIP Adv. Inf. Commun. Technol. 2017, 514, 411-418. [CrossRef]

20. Koksharov, V.; Starodubets, N.; Ponomareva, M. Assessment of an enterprise circular economy development. WSEAS Trans. Bus. Econ. 2019, 16, 559-567.

21. Okorie, O.; Salonitis, K.; Charnley, F.; Moreno, M.; Turner, C.; Tiwari, A. Digitisation and the circular economy: A review of current research and future trends. Energies 2018, 11, 3009. [CrossRef]

22. Kircherr, J.; Hekkert, M.; Bour, R.; Huibrechtse-Truijens, A.; Kostense-Smit, E.; Muller, J. Breaking the barriers to the circular economy. Deloitte 2017. Available online: https:/ / www2.deloitte.com/nl/nl/pages/risk/articles/breaking-the-barriers-to-thecircular-economy.html (accessed on 4 March 2021).

23. Ellen MacArthur Foundation. Towards the Circular Economy Vol. 1: An Economic and Business Rationale for an Accelerated Transition; Ellen MacArthur Foundation: Cowes, UK, 2012. Available online: https://www.ellenmacarthurfoundation.org/ publications / towards-the-circular-economy-vol-1-an-economic-and-business-rationale-for-an-accelerated-transition (accessed on 4 March 2021).

24. Cayzer, S.; Griffiths, P.; Beghetto, V. Design of indicators for measuring product performance in the circular economy. Int. J. Sustain. Eng. 2017, 10, 289-298. [CrossRef]

25. de Ferreira, A.C.; Fuso-Nerini, F. A framework for implementing and tracking circular economy in cities: The case of Porto. Sustainability 2019, 11, 1813. [CrossRef]

26. Ellen MacArthur Foundation. Growth within: A Circular Economy Vision for a Competitive Europe; Ellen MacArthur Foundation: Cowes, UK, 2015. Available online: https://www.ellenmacarthurfoundation.org/publications/growth-within-a-circulareconomy-vision-for-a-competitive-europe (accessed on 4 March 2021).

27. Lewandowski, M. Designing the business models for circular economy-Towards the conceptual framework. Sustainability 2016, 8, 43. [CrossRef]

28. Ellen MacArthur Foundation. The role of business strategies in catalysing the transition towards a Circular Economy. In Proceedings of the North London Waste Prevention Exchange, London, UK, 16 February 2017.

29. Kalmykova, Y.; Sadagopan, M.; Rosado, L. Circular economy-From review of theories and practices to development of implementation tools. Resour. Conserv. Recycl. 2018, 135, 190-201. [CrossRef] 
30. Merli, R.; Preziosi, M.; Acampora, A. How do scholars approach the circular economy? A systematic literature review. J. Clean. Prod. 2018, 178, 703-722. [CrossRef]

31. Rosa, P.; Sassanelli, C.; Urbinati, A.; Chiaroni, D.; Terzi, S. Assessing relations between circular economy and Industry 4.0: A systematic literature review. Int. J. Prod. Res. 2020, 58, 1662-1687. [CrossRef]

32. Ministero dello Sviluppo Economico. Piano Nazionale Industria 4.0; 2017. Available online: https://www.mise.gov.it/images/ stories/documenti/guida_industria_40.pdf (accessed on 4 March 2021).

33. Miqueo, A.; Torralba, M.; Yagüe-Fabra, J.A. Lean manual assembly 4.0: A systematic review. Appl. Sci. 2020, 10, 8555. [CrossRef]

34. Nasiri, M.; Tura, N.; Ojanen, V. Developing disruptive innovations for sustainability: A review on Impact of Internet of Things (IOT). In Proceedings of the 2017 Portland International Conference on Management of Engineering and Technology (PICMET), Portland, OR, USA, 9-13 July 2017; pp. 1-10.

35. De Mauro, A.; Greco, M.; Grimaldi, M. A formal definition of Big Data based on its essential features. Libr. Rev. 2016, 65, 122-135. [CrossRef]

36. Mell, P.; Grance, T. The NIST Definition of Cloud Computing. Recommendations of the National Institute of Standards and Technology; Computer Security Division, Information Technology Laboratory, National Institute of Standards and Technology: Gaithersburg, MD, USA, 2011.

37. Schatz, D.; Bashroush, R.; Wall, J. Towards a more representative definition of cyber security. J. Digit. Forensics Secur. Law 2017, 12, 53-74. [CrossRef]

38. Pérez-Lara, M.; Saucedo-Martínez, J.A.; Marmolejo-Saucedo, J.A.; Salais-Fierro, T.E.; Vasant, P. Vertical and horizontal integration systems in Industry 4.0. Wirel. Netw. 2020, 26, 4767-4775. [CrossRef]

39. Abari, O.; Bharadia, D.; Duffield, A.; Katabi, D. Enabling high-quality untethered virtual reality. In Proceedings of the 14th USENIX Symposium on Networked Systems Design and Implementation, Boston, MA, USA, 27-29 March 2017.

40. Fragapane, G.; Ivanov, D.; Peron, M.; Sgarbossa, F.; Strandhagen, J.O. Increasing flexibility and productivity in Industry 4.0 production networks with autonomous mobile robots and smart intralogistics. Ann. Oper. Res. 2020, 1-19. [CrossRef]

41. Guo, N.; Leu, M.C. Additive manufacturing: Technology, applications and research needs. Front. Mech. Eng. 2013, 8, 215-243. [CrossRef]

42. Tranfield, D.; Denyer, D. Producing a systematic review. Sage Handb. Organ. Res. Methods 2009, 39, $672-688$.

43. Liberati, A.; Altman, D.G.; Tetzlaff, J.; Mulrow, C.; Gøtzsche, P.C.; Ioannidis, J.P.A.; Clarke, M.; Devereaux, P.J.; Kleijnen, J.; Moher, D. The PRISMA statement for reporting systematic reviews and meta-analyses of studies that evaluate health care interventions: Explanation and elaboration. J. Clin. Epidemiol. 2009, 62, e1-e34. [CrossRef] [PubMed]

44. Denyer, D.; Tranfield, D.; Van Aken, J.E. Developing design propositions through research synthesis. Organ. Stud. 2008, 29, 393-413. [CrossRef]

45. Palmaccio, M.; Dicuonzo, G.; Belyaeva, Z.S. The internet of things and corporate business models: A systematic literature review. J. Bus. Res. 2020, 1-9. [CrossRef]

46. Roos Lindgreen, E.; Salomone, R.; Reyes, T. A critical review of academic approaches, methods and tools to assess circular economy at the micro level. Sustainability 2020, 12, 4973. [CrossRef]

47. Liao, Y.; Deschamps, F.; Loures, E.d.F.R.; Ramos, L.F.P. Past, present and future of Industry 4.0-A systematic literature review and research agenda proposal. Int. J. Prod. Res. 2017, 55, 3609-3629. [CrossRef]

48. Awan, U.; Sroufe, R.; Shahbaz, M. Industry 4.0 and the circular economy: A literature review and recommendations for future research. Bus. Strateg. Environ. 2021. [CrossRef]

49. Munirathinam, S. Industry 4.0: Industrial Internet of Things (IIOT). In The Digital Twin Paradigm for Smarter Systems and Environments: The Industry Use Cases; Raj, P., Evangeline, P.B.T.-A., Eds.; Academic Press: Cambridge, MA, USA; San Diego, CA, USA; Oxford, UK; London, UK, 2020; Volume 117, pp. 129-164, ISBN 0065-2458.

50. Lee, J.; Davari, H.; Singh, J.; Pandhare, V. Industrial artificial intelligence for industry 4.0-based manufacturing systems. Manuf. Lett. 2018, 18, 20-23. [CrossRef]

51. Moher, D.; Liberati, A.; Tetzlaff, J.; Altman, D.G. Preferred reporting items for systematic reviews and meta-analyses: The PRISMA statement. PLoS Med. 2009, 6, e1000097. [CrossRef]

52. Heckathorn, D.D.; Cameron, C.J. Network sampling: From snowball and multiplicity to respondent-driven sampling. Annu. Rev. Sociol. 2017, 43, 101-119. [CrossRef]

53. Harris, S.; Martin, M.; Diener, D. Circularity for circularity's sake? Scoping review of assessment methods for environmental performance in the circular economy. Sustain. Prod. Consum. 2021, 26, 172-186. [CrossRef]

54. Upadhyay, A.; Mukhuty, S.; Kumar, V.; Kazancoglu, Y. Blockchain technology and the circular economy: Implications for sustainability and social responsibility. J. Clean. Prod. 2021, 293, 126130. [CrossRef]

55. Chiappetta Jabbour, C.J.; Lopes de Sousa Jabbour, A.B.; Sarkis, J.; Filho, M.G. Unlocking the circular economy through new business models based on large-scale data: An integrative framework and research agenda. Technol. Forecast. Soc. Chang. 2019, 144, 546-552. [CrossRef]

56. Maestrini, V.; Luzzini, D.; Maccarrone, P.; Caniato, F. Supply chain performance measurement systems: A systematic review and research agenda. Int. J. Prod. Econ. 2017, 183, 299-315. [CrossRef]

57. Strozzi, F.; Colicchia, C.; Creazza, A.; Noè, C. Literature review on the 'Smart Factory' concept using bibliometric tools. Int. J. Prod. Res. 2017, 55, 6572-6591. [CrossRef] 
58. Neri, A.; Cagno, E.; Di Sebastiano, G.; Trianni, A. Industrial sustainability: Modelling drivers and mechanisms with barriers. J. Clean. Prod. 2018, 194, 452-472. [CrossRef]

59. Okorie, O.; Charnley, F.; Russell, J.; Tiwari, A.; Moreno, M. Circular business models in high value manufacturing: Five industry cases to bridge theory and practice. Bus. Strateg. Environ. 2021, bse.2715. [CrossRef]

60. Ranta, V.; Aarikka-Stenroos, L.; Väisänen, J.M. Digital technologies catalyzing business model innovation for circular economyMultiple case study. Resour. Conserv. Recycl. 2021, 164, 105155. [CrossRef]

61. Rehman Khan, S.A.; Yu, Z.; Sarwat, S.; Godil, D.I.; Amin, S.; Shujaat, S. The role of block chain technology in circular economy practices to improve organisational performance. Int. J. Logist. Res. Appl. 2021. [CrossRef]

62. Bag, S.; Wood, L.C.; Mangla, S.K.; Luthra, S. Procurement 4.0 and its implications on business process performance in a circular economy. Resour. Conserv. Recycl. 2020, 152, 104502. [CrossRef]

63. Bag, S.; Yadav, G.; Wood, L.C.; Dhamija, P.; Joshi, S. Industry 4.0 and the circular economy: Resource melioration in logistics. Resour. Policy 2020, 68, 101776. [CrossRef]

64. Bag, S.; Pretorius, J.H.C. Relationships between industry 4.0, sustainable manufacturing and circular economy: Proposal of a research framework. Int. J. Organ. Anal. 2020. [CrossRef]

65. Cwiklicki, M.; Wojnarowska, M. Circular economy and industry 4.0: One-way or two-way relationships? Eng. Econ. 2020, 31, 387-397. [CrossRef]

66. De Marchi, V.; Di Maria, E. Achieving circular economy via the adoption of Industry 4.0 technologies: A Knowledge management perspective. In Knowledge Management and Organizational Learning; Springer: Cham, Switzerland, 2020; pp. 163-178.

67. Demestichas, K.; Daskalakis, E. Information and communication technology solutions for the circular economy. Sustainability 2020, 12, 7272. [CrossRef]

68. Dev, N.K.; Shankar, R.; Qaiser, F.H. Industry 4.0 and circular economy: Operational excellence for sustainable reverse supply chain performance. Resour. Conserv. Recycl. 2020, 153, 104583. [CrossRef]

69. Esmaeilian, B.; Sarkis, J.; Lewis, K.; Behdad, S. Blockchain for the future of sustainable supply chain management in Industry 4.0. Resour. Conserv. Recycl. 2020, 163, 105064. [CrossRef]

70. Favi, C.; Marconi, M.; Mandolini, M.; Germani, M. Big data analysis for the estimation of disassembly time and de-manufacturing activity. Procedia CIRP 2020, 90, 617-622. [CrossRef]

71. Getor, R.Y.; Mishra, N.; Ramudhin, A. The role of technological innovation in plastic production within a circular economy framework. Resour. Conserv. Recycl. 2020, 163, 105094. [CrossRef]

72. Ghoreishi, M.; Happonen, A. Key enablers for deploying artificial intelligence for circular economy embracing sustainable product design: Three case studies. In AIP Conference Proceedings, Proceedings of the 2 nd Science and Mathematics International Conference (SMIC 2020): Transforming Research and Education of Science and Mathematics in the Digital Age, Jakarta, Indonesia, 8-9 August 2020; AIP Publishing: College Park, MD, USA, 2021; Volume 2233, p. 050008.

73. Ingemarsdotter, E.; Jamsin, E.; Balkenende, R. Opportunities and challenges in IoT-enabled circular business model implementation: A case study. Resour. Conserv. Recycl. 2020, 162, 105047. [CrossRef]

74. Kintscher, L.; Lawrenz, S.; Poschmann, H.; Sharma, P. Recycling 4.0-digitalization as a key for the advanced circular economy. J. Commun. 2020, 15, 652-660. [CrossRef]

75. Kouhizadeh, M.; Zhu, Q.; Sarkis, J. Blockchain and the circular economy: Potential tensions and critical reflections from practice. Prod. Plan. Control 2020, 31, 950-966. [CrossRef]

76. Kravchenko, M.; Pigosso, D.C.A.; McAloone, T.C. Circular economy enabled by additive manufacturing: Potential opportunities and key sustainability aspects. In Proceedings of the Balancing Innovation and Operation; The Design Society, Lyngby, Denmark, 12-14 August 2020.

77. Kristoffersen, E.; Blomsma, F.; Mikalef, P.; Li, J. The smart circular economy: A digital-enabled circular strategies framework for manufacturing companies. J. Bus. Res. 2020, 120, 241-261. [CrossRef]

78. Mboli, J.S.; Thakker, D.; Mishra, J.L. An Internet of things-enabled decision support system for circular economy business model. Softw. Pract. Exp. 2020, 1-16. [CrossRef]

79. Moller, D.P.F. Enhancement in intelligent manufacturing through circular economy. In Proceedings of the 2020 IEEE International Conference on Electro Information Technology (EIT), Chicago, IL, USA, 31 July-1 August 2020; pp. 87-92.

80. Nobre, G.C.; Tavares, E. Assessing the role of big data and the internet of things on the transition to circular economy: Part I an extension of the ReSOLVE framework proposal through a literature review. Johns. Matthey Technol. Rev. 2020, 64, 19-31. [CrossRef]

81. Nobre, G.C.; Tavares, E. Assessing the role of big data and the internet of things on the transition to circular economy: Part II: An extension of the ReSOLVE framework proposal through a literature review. Johns. Matthey Technol. Rev. 2020, 64, 32-41. [CrossRef]

82. Piscitelli, G.; Ferazzoli, A.; Petrillo, A.; Cioffi, R.; Parmentola, A.; Travaglioni, M. Circular economy models in the industry 4.0 era: A review of the last decade. Procedia Manuf. 2020, 42, 227-234. [CrossRef]

83. Poschmann, H.; Brüggemann, H.; Goldmann, D. Disassembly 4.0: A review on using robotics in disassembly tasks as a way of automation. Chemie Ing. Tech. 2020, 92, 341-359. [CrossRef]

84. Rajput, S.; Singh, S.P. Industry 4.0 Model for circular economy and cleaner production. J. Clean. Prod. 2020, 277, 123853. [CrossRef] 
85. Rocca, R.; Rosa, P.; Sassanelli, C.; Fumagalli, L.; Terzi, S. Integrating virtual reality and digital twin in circular economy practices: A laboratory application case. Sustainability 2020, 12, 2286. [CrossRef]

86. Rossi, J.; Bianchini, A.; Guarnieri, P. Circular Economy model enhanced by intelligent assets from Industry 4.0: The proposition of an innovative tool to analyze case studies. Sustainability 2020, 12, 7147. [CrossRef]

87. Uçar, E.; Le Dain, M.A.; Joly, I. Digital technologies in circular economy transition: Evidence from case studies. Procedia CIRP 2020, 90, 133-136. [CrossRef]

88. Yadav, G.; Luthra, S.; Jakhar, S.K.; Mangla, S.K.; Rai, D.P. A framework to overcome sustainable supply chain challenges through solution measures of industry 4.0 and circular economy: An automotive case. J. Clean. Prod. 2020, 254, 120112. [CrossRef]

89. Alcayaga, A.; Wiener, M.; Hansen, E.G. Towards a framework of smart-circular systems: An integrative literature review. J. Clean. Prod. 2019, 221, 622-634. [CrossRef]

90. Cezarino, L.O.; Liboni, L.B.; Oliveira Stefanelli, N.; Oliveira, B.G.; Stocco, L.C. Diving into emerging economies bottleneck: Industry 4.0 and implications for circular economy. Manag. Decis. 2019. [CrossRef]

91. Charnley, F.; Tiwari, D.; Hutabarat, W.; Moreno, M.; Okorie, O.; Tiwari, A. Simulation to enable a data-driven circular economy. Sustainability 2019, 11, 3379. [CrossRef]

92. Garcia-Muiña, F.E.; González-Sánchez, R.; Ferrari, A.M.; Volpi, L.; Pini, M.; Siligardi, C.; Settembre-Blundo, D. Identifying the equilibrium point between sustainability goals and circular economy practices in an Industry 4.0 manufacturing context using eco-design. Soc. Sci. 2019, 8, 241. [CrossRef]

93. Garrido-Hidalgo, C.; Olivares, T.; Ramirez, F.J.; Roda-Sanchez, L. An end-to-end internet of things solution for reverse supply chain management in Industry 4.0. Comput. Ind. 2019. [CrossRef]

94. Gligoric, N.; Krco, S.; Hakola, L.; Vehmas, K.; De, S.; Moessner, K.; Jansson, K.; Polenz, I.; van Kranenburg, R. SmartTags: IoT product passport for circular economy based on printed sensors and unique item-level identifiers. Sensors 2019, $19,586$. [CrossRef] [PubMed]

95. Ingemarsdotter, E.; Jamsin, E.; Kortuem, G.; Balkenende, R. Circular strategies enabled by the internet of things-A framework and analysis of current practice. Sustainability 2019, 11, 5689. [CrossRef]

96. Kerin, M.; Pham, D.T. A review of emerging industry 4.0 technologies in remanufacturing. J. Clean. Prod. 2019, 237, 117805 [CrossRef]

97. Moreno, M.; Court, R.; Wright, M.; Charnley, F. Opportunities for redistributed manufacturing and digital intelligence as enablers of a circular economy. Int. J. Sustain. Eng. 2019, 12, 77-94. [CrossRef]

98. Nascimento, D.L.M.; Alencastro, V.; Quelhas, O.L.G.; Caiado, R.G.G.; Garza-Reyes, J.A.; Lona, L.R.; Tortorella, G. Exploring Industry 4.0 technologies to enable circular economy practices in a manufacturing context: A business model proposal. J. Manuf. Technol. Manag. 2019, 30, 607-627. [CrossRef]

99. Pham, T.T.; Kuo, T.-C.; Tseng, M.-L.; Tan, R.R.; Tan, K.; Ika, D.S.; Lin, C.J. Industry 4.0 to accelerate the circular economy: A case study of electric scooter sharing. Sustainability 2019, 11, 6661. [CrossRef]

100. Rajput, S.; Singh, S.P. Industry 4.0—Challenges to implement circular economy. Benchmarking Int. J. 2019. [CrossRef]

101. Rajput, S.; Singh, S.P. Connecting circular economy and Industry 4.0. Int. J. Inf. Manag. 2019, 49, 98-113. [CrossRef]

102. Riesener, M.; Dolle, C.; Mattern, C.; Kres, J. Circular economy: Challenges and potentials for the manufacturing industry by digital transformation. In Proceedings of the 2019 IEEE International Symposium on Innovation and Entrepreneurship (TEMS-ISIE), Hangzhou, China, 24-26 October 2019; pp. 1-7.

103. Sarc, R.; Curtis, A.; Kandlbauer, L.; Khodier, K.; Lorber, K.E.; Pomberger, R. Digitalisation and intelligent robotics in value chain of circular economy oriented waste management: A review. Waste Manag. 2019, 95, 476-492. [CrossRef]

104. Väisänen, J.-M.; Ranta, V.; Aarikka-Stenroos, L. Enabling circular economy with software: A multi-level approach to benefits, requirements and barriers. In Lecture Notes in Business Information Processing; Springer: Cham, Switzerland, 2019; pp. 252-259, ISBN 9783030337414.

105. Bianchini, A.; Pellegrini, M.; Rossi, J.; Saccani, C. A new productive model of circular economy enhanced by digital transformation in the Fourth Industrial Revolution-An integrated framework and real case studies. In Proceedings of the 23rd Summer School Francesco Turco, Palermo, Italy, 12-14 September 2018; pp. 221-227.

106. Bressanelli, G.; Adrodegari, F.; Perona, M.; Saccani, N. Exploring how usage-focused business models enable circular economy through digital technologies. Sustainability 2018, 10, 639. [CrossRef]

107. Bressanelli, G.; Adrodegari, F.; Perona, M.; Saccani, N. The role of digital technologies to overcome circular economy challenges in PSS Business Models: An exploratory case study. Procedia CIRP 2018, 73, 216-221. [CrossRef]

108. Makarova, I.; Shubenkova, K.; Pashkevich, A. The Concept of the decision support system to plan the reverse logistics in automotive industry. In Proceedings of the 2018 26th International Conference on Software, Telecommunications and Computer Networks (SoftCOM), Supetar, Croatia, 13-15 September 2018; pp. 1-6.

109. Neligan, A. Digitalisation as enabler towards a sustainable circular economy in Germany. Intereconomics 2018, 53, 101-106. [CrossRef]

110. Pagoropoulos, A.; Pigosso, D.C.A.; McAloone, T.C. The emergent role of digital technologies in the circular economy: A review. Procedia CIRP 2017, 64, 19-24. [CrossRef]

111. Moreno, M.; Charnley, F. Can re-distributed manufacturing and digital intelligence enable a regenerative economy? An integrative literature review. Smart Innov. Syst. Technol. 2016, 52, 563-575. [CrossRef] 
112. Reuter, M.A. Digitalizing the circular economy: Circular economy engineering defined by the metallurgical internet of things. Metall. Mater. Trans. B 2016, 47, 3194-3220. [CrossRef]

113. Yadav, G.; Mangla, S.K.; Bhattacharya, A.; Luthra, S. Exploring indicators of circular economy adoption framework through a hybrid decision support approach. J. Clean. Prod. 2020, 277, 124186. [CrossRef]

114. Erro-Garcés, A. Industry 4.0: Defining the research agenda. Benchmarking Int. J. 2019. [CrossRef]

115. Lu, Q.; Xu, X. Adaptable blockchain-based systems: A case study for product traceability. IEEE Softw. 2017, 34, 21-27. [CrossRef]

116. Fosso Wamba, S.; Akter, S.; Edwards, A.; Chopin, G.; Gnanzou, D. How "big data" can make big impact: Findings from a systematic review and a longitudinal case study. Int. J. Prod. Econ. 2015, 165, 234-246. [CrossRef]

117. Fang, H.C.; Ong, S.K.; Nee, A.Y.C. Use of embedded smart sensors in products to facilitate remanufacturing. In Handbook of Manufacturing Engineering and Technology; Nee, A.Y.C., Ed.; Springer: London, UK, 2015; pp. 3265-3290, ISBN 978-1-4471-4670-4.

118. Yang, S.; Raghavendra, M.R.A.; Kaminski, J.; Pepin, H. Opportunities for Industry 4.0 to support remanufacturing. Appl. Sci. 2018, 8, 1177. [CrossRef]

119. Ford, S.; Despeisse, M. Additive manufacturing and sustainability: An exploratory study of the advantages and challenges. J. Clean. Prod. 2016, 137, 1573-1587. [CrossRef]

120. de Souza, F.F.; Ferreira, M.B.; Saraceni, A.V.; Betim, L.M.; Pereira, T.L.; Petter, R.R.H.; Pagani, R.N.; de Resende, L.M.M.; Pontes, J.; Piekarski, C.M.; et al. Temporal comparative analysis of industrial symbiosis in a business network: Opportunities of circular economy. Sustainability 2020, 12, 1832. [CrossRef]

121. Zhu, Y.; Dawande, M.; Gavirneni, N.; Jayaraman, V. Industrial symbiosis: Impact of competition on firms' willingness to implement. IISE Trans. 2020, 1-17. [CrossRef]

122. Martin, M. Industrial symbiosis networks: Application of the circular economy for resource efficiency. In Handbook of the Circular Economy; Brandão, M., Finnveden, D., Göran, F., Eds.; Edward Elgar Publishing: Cheltenham, UK, 2020; pp. 50-60.

123. Fraccascia, L.; Yazan, D.M. The role of online information-sharing platforms on the performance of industrial symbiosis networks. Resour. Conserv. Recycl. 2018, 136, 473-485. [CrossRef]

124. Ranta, V.; Aarikka-Stenroos, L.; Ritala, P.; Mäkinen, S.J. Exploring institutional drivers and barriers of the circular economy: A cross-regional comparison of China, the US, and Europe. Resour. Conserv. Recycl. 2018, 135, 70-82. [CrossRef]

125. Horváth, D.; Szabó, R.Z. Driving forces and barriers of Industry 4.0: Do multinational and small and medium-sized companies have equal opportunities? Technol. Forecast. Soc. Chang. 2019, 146, 119-132. [CrossRef]

126. Herceg, I.V.; Kuč, V.; Mijušković, V.M.; Herceg, T. Challenges and driving forces for industry 4.0 implementation. Sustainability 2020, 12, 4208. [CrossRef]

127. Raj, A.; Dwivedi, G.; Sharma, A.; Lopes de Sousa Jabbour, A.B.; Rajak, S. Barriers to the adoption of industry 4.0 technologies in the manufacturing sector: An inter-country comparative perspective. Int. J. Prod. Econ. 2020, 224, 107546. [CrossRef]

128. Bogoviz, A.V.; Osipov, V.S.; Chistyakova, M.K.; Borisov, M.Y. Comparative analysis of formation of Industry 4.0 in developed and developing countries. In Industry 4.0: Industrial Revolution of the 21st Century. Studies in Systems, Decision and Control; Popkova, E., Ragulina, Y., Bogoviz, A., Eds.; Springer: Cham, Switzerland, 2019; pp. 155-164.

129. Pozzi, R.; Rossi, T.; Secchi, R. Industry 4.0 technologies: Critical success factors for implementation and improvements in manufacturing companies. Prod. Plan. Control 2021, 1-21. [CrossRef]

130. Cagno, E.; Neri, A.; Howard, M.; Brenna, G.; Trianni, A. Industrial sustainability performance measurement systems: A novel framework. J. Clean. Prod. 2019, 230, 1354-1375. [CrossRef]

131. Neri, A.; Cagno, E.; Lepri, M.; Trianni, A. A triple bottom line balanced set of key performance indicators to measure the sustainability performance of industrial supply chains. Sustain. Prod. Consum. 2021, 26, 648-689. [CrossRef]

132. Garza-Reyes, J.A.; Salomé Valls, A.; Peter Nadeem, S.; Anosike, A.; Kumar, V. A circularity measurement toolkit for manufacturing SMEs. Int. J. Prod. Res. 2019, 57, 7319-7343. [CrossRef]

133. Trianni, A.; Cagno, E.; Neri, A. Modelling barriers to the adoption of industrial sustainability measures. J. Clean. Prod. 2017, 168, 1482-1504. [CrossRef]

134. Luthra, S.; Kumar, A.; Zavadskas, E.K.; Mangla, S.K.; Garza-Reyes, J.A. Industry 4.0 as an enabler of sustainability diffusion in supply chain: An analysis of influential strength of drivers in an emerging economy. Int. J. Prod. Res. 2020, 58, 1505-1521. [CrossRef]

135. Demartini, M.; Evans, S.; Tonelli, F. Digitalization technologies for industrial sustainability. Procedia Manuf. 2019, 33, $264-271$. [CrossRef]

136. Schneider, S. The Impacts of Digital Technologies on Innovating for Sustainability. In Innovation for Sustainability; Bocken, N., Ritala, P., Albareda, L., Verburg, R., Eds.; Palgrave Macmillan: Cham, Switzerland, 2019; pp. 415-433. [CrossRef]

137. Trianni, A.; Cagno, E.; Neri, A.; Howard, M. Measuring industrial sustainability performance: Empirical evidence from Italian and German manufacturing small and medium enterprises. J. Clean. Prod. 2019, 229, 1355-1376. [CrossRef]

138. Mura, M.; Longo, M.; Zanni, S. Circular economy in Italian SMEs: A multi-method study. J. Clean. Prod. 2020, $245,118821$. [CrossRef]

139. Chonsawat, N.; Sopadang, A. Defining SMEs' 4.0 readiness indicators. Appl. Sci. 2020, 10, 8998. [CrossRef]

140. Pech, M.; Vrchota, J. Classification of small- and medium-sized enterprises based on the level of Industry 4.0 implementation. Appl. Sci. 2020, 10, 5150. [CrossRef] 
141. de Jesus, C.; Lima, R.M. Literature search of key factors for the development of generic and specific maturity models for Industry 4.0. Appl. Sci. 2020, 10, 5825. [CrossRef]

142. Klein, N.; Ramos, T.B.; Deutz, P. Circular economy practices and strategies in public sector organizations: An integrative review. Sustainability 2020, 12, 4181. [CrossRef]

143. Almada-Lobo, F. The Industry 4.0 revolution and the future of Manufacturing Execution Systems (MES). J. Innov. Manag. 2016, 3, 16-21. [CrossRef]

144. Boccella, A.R.; Centobelli, P.; Cerchione, R.; Murino, T.; Riedel, R. Evaluating centralized and heterarchical control of smart manufacturing systems in the era of Industry 4.0. Appl. Sci. 2020, 10, 755. [CrossRef]

145. Pilo, F.; Pisano, G.; Coppo, M. Cooperative centralised and decentralised energy management. In Proceedings of the International Conference on Electricity Distribution, Lyon, France, 15-18 June 2015; pp. 15-18.

146. Fiorini, L.; Aiello, M. Energy management for user's thermal and power needs: A survey. Energy Rep. 2019, 5, 1048-1076. [CrossRef]

147. Yin, R.K. Case Study Research Design and Methods, 4th ed.; SAGE: Thousand Oaks, CA, USA, 2009.

148. Voss, C.; Tsikriktsis, N.; Frohlich, M. Case research in operations management. Int. J. Oper. Prod. Manag. 2002, 22, 195-219. [CrossRef]

149. Meredith, J. Building operations management theory through case and field research. J. Oper. Manag. 1998, 16, 441-454. [CrossRef]

150. Camarinha-Matos, L.M.; Fornasiero, R.; Ramezani, J.; Ferrada, F. Collaborative networks: A pillar of digital transformation. Appl. Sci. 2019, 9, 5431. [CrossRef] 